\title{
Abstracts of the ASHS Southern Region 55th Annual Meeting
}

\section{J.B. Edmond}

ALTERNATIVES IN MEDIA: FINDING RENEWABLE SUBSTITUTES FOR PEATMOSS

LeAnne Newell* and Janet C. Cole, Department of Horticulture and Landscape Architecture, Oklahoma State University, 360 Ag Hall, Stillwater, OK 74078

WetEarth, a processed recycled newspaper product, was used in combination with pine bark, sand, and vermiculite as a growing medium for rose of Sharon and forsythia. Rose of Sharon was taller and had more leaves; more leaf area per plant; and greater leaf, stem, and root dry weights in all media containing recycled paper compared to plants grown in a medium consisting of 3 pine bark : 1 peat moss : 1 sand (by volume) (control). Forsythia grown in the control media were taller than those grown in any medium containing recycled newspaper. There was no difference in number of leaves per plant or leaf area of forsythia, regardless of growing medium. Physical and chemical properties of each medium also were investigated. All media containing recycled newspaper had a higher $\mathrm{pH}$, porosity, and air space than the control medium.

\section{CULTIVAR AND IBA CONCENTRATION INFLUENCE ROOT-} ING OF BUDDLEIA

C.C. Montgomery, B.K. Behe, D.J. Eakes T.S. Krentz, and V.V. Allen, Department of Horticulture, 101 Funchess Hall, Auburn University, AL 36849-5408

Buddleia, or butterfly bush, is a popular landscape plant because it attracts wildlife and has some heat and drought tolerance. Dirr and Heuser reported that softwood cuttings of most cultivars rooted well with a basal treatment of 3000 ppm IBA. A rooting study of 11 Buddleia cultivars was conducted in Sept. 1993 and was repeated in May 1994. Terminal softwood cuttings were treated with a quick dip of $0,1500,3000,6000 \mathrm{ppm}$ K-IBA. Generally, increasing rates of IBA increased root count and decreased root length. Root dry weight was minimally affected. 'Royal Red', 'Empire Blue', and 'Lochinch' had $94 \%$ to $95 \%$ rooted cuttings. Other cultivars rooted equally better. Most cultivars produced shorter, more numerous roots in spring when a higher IBA concentration was used.

GROWTH AND ECONOMIC ASSESSMENTS OF KENAF CORE AS THE MAJOR COMPONENT IN GREENHOUSE POTTING MEDIA

$\underline{\text { R. Dudley Williams* and Nancy A. Reichert, Department of Plant and }}$ Soil Sciences, Mississippi State University, Box 9555, Mississippi State, MS 39762

Two types of ground kenaf core (fresh and aged) were used in concentrations from $70 \%$ to $100 \%(\mathrm{v} / \mathrm{v})$ in combination with peat for use as greenhouse potting media and were compared to two commercial mixes in completely randomized block designs. Greenhouse crops of Boston fern (Nephrolepis), impatiens, and pansies (Viola) were grown in the different mixes. Irrigation was conducted regularly, based primarily on the average need of all the plants. Kenaf-based media did not retain water as well as the commercial mixes. Consequently, impatiens and pansies displayed slower growth rates. However, no differences were noted for fern growth in $70 \%$ kenaf compared to commercial mixes. A second study on plants that were grouped by media type and watered as needed provided different results. Ferns grew equally well in all media, but impatiens grew best in $70 \%$ fresh kenaf. Kenaf-based media were less costly than the commercial mixes, and the cost decreased steadily as the kenaf proportion increased. The lower cost of kenaf coupled with the decreasing availability of peat should make kenaf-based media an attractive alternative to conventional greenhouse potting media.

\section{INDIVIDUAL STUDIES IN WOODY PLANT PROPAGATION} Carlton C. Davidson*, Jeff L. Sibley, and D. Joseph Eakes, Department of Horticulture, Auburn University, AL 36849

Traditional propagation courses seldom allow extensive evaluation of the variables required for successful propagation. A series of experiments were designed to give an individual student practical experience in woody plant propagation. Softwood terminal cuttings were taken on five shrub or tree species, dividing each species into separate experiments comparing talc vs. liquid auxin formulations. Selections evaluated included luster leaf holly with treatments of 3000 , 8000, and 16,000 ppm K-IBA; hetz holly, crape myrtle, and anise tree with treatments of 1000,3000 , and 8000 ppm K-IBA; and sugar maple with 8000 and 16,000 ppm K-IBA. Budding and seed propagation also were evaluated in sugar maple. In each species, except sugar maple, liquid quick-dip at the highest K-IBA concentration produced the best rooting. The student gained many educational benefits in basic experimental design, evaluation of data collected, and drawing conclusions to findings significant by industry standards. The student also learned and how production cycles have an impact on various methods, development stages of cutting material, and wounding techniques. The practical propagation experience gained was of primary importance thereby further preparing the student for employment in the industry.

\section{Norman F. Childers Graduate Papers}

EFFECTS OF NITROGEN RATES AND FINAL FALL HARVEST TIMING ON SAGE (SALVIA OFFICINALIS)

N.E. Maness, J.E. Motes, and B. Bostian, Department of Horticulture and Landscape Architecture; and R.J. Schatzer, Department of Agriculture Economics, Oklahoma State University, Stillwater, OK 74078

Sage is a perennial, semi-evergreen herb and is a multiharvest crop. 
In a 4-year field study in Bixby, Okla., three $\mathrm{N}$ rates, including 60, 120, and $180 \mathrm{~kg} / \mathrm{h}$, and four fall harvest dates, including 40 and 20 days before the average first freeze date in Bixby, the average freeze date, and 20 days past the average freeze date were evaluated on sage (Salvia officinalis) production. The fall harvest dates were $\approx 20$ Sept., 10 Oct., 1 Nov., or 20 Nov. each year. Plots were established with transplants in Spring 1990. On all plots, growing-season harvests were executed once in spring and once in summer, followed by the final harvest in the fall annually (1991 to 1994). Results indicated $\mathrm{N}$ effects on yield and the $\mathrm{N} \times$ final fall harvest date interaction were not significant for any of the years. Yields were significantly reduced in the 40 and 20 days prefreeze date harvest treatment plots in 1992, 1993, and 1994 by a hard freeze of $-7 \mathrm{C}$ on 2 Nov. 1991 with no prior killing frost. Plant stand loss was $61 \%$ and $8 \%$ in the 40 and 20 days prefreeze harvested plots, respectively. Injury, but not plant loss, in the 20 days prefreeze harvested plots contributed to the yield reduction. Yields in the two later final harvest treatment plots were not affected.

\section{DNA AMPLIFICATION FINGERPRINTING (DAF) IDENTIFIES CLOSELY RELATED CULTIVARS IN THREE SERIES OF CHRY- SANTHEMUMS}

M.C. Scott*, G. Caetano-Anollés, and R.N. Trigiano, Department Ornamental Horticulture and Landscape Design, The University of Tennessee, Knoxville, TN 37901-1071

The genetic distance of closely related cultivars of Dendranthema grandiflora (chrysanthemum) was assessed using DAF. Thirteen cultivars of chrysanthemum included in the study were members of the following series: Charm (five), Davis (four), and Pomona (four). The genetic variability within and between series were evaluated using 11 arbitrary octamer primers. A few polymorphic loci were evident that uniquely identified closely related cultivars within a series. In contrast, there were many polymorphisms between members of different series. Genetic distances between cultivars within and between series were calculated using marker comparison and UPGMA (cluster analysis). The average distance between series was 10-fold greater than between cultivars within a series. DNA from all cultivars belonging to a series also were bulked to generate DNA profiles containing unique amplified products for each series. Polymorphic loci that were generated by the DAF technique possibly could be used for patent protection and phylogenetic studies and may be useful in breeding for chrysanthemums.

\section{Vegetable Crops}

INCIDENCE AND SEVERITY OF WATERMELON (CITRULLUS LANATUS) HOLLOWHEART

G.W. Elmstrom and F. McCuistion, Jr., University of Florida, 5336 University Avenue, Leesburg, FL 34748; and D. N. Maynard*, University of Florida, 5007 60th Street East, Bradenton, FL 34203

Watermelon varieties were evaluated for hollowheart $(\mathrm{HH})$ at Bradenton, Leesburg, and Quincy, Fla. HH varied with location, variety, and season. Among icebox varieties, 'Sugar Baby', 'Baby Gray', and SSDL had less HH than 'Tiger Baby', 'Minilee', and 'Mickylee'. Among standard varieties, 'Sangria' and 'Jubilee II' had less HH than 'Crimson Sweet' and 'Royal Sweet'. In 1990, HH was more severe at Quincy than at Bradenton or Leesburg, but the ranking of seedless entries was similar among the locations. HMX 7928, 'Nova', 'Tycoon', and 'Millionaire' had least HH, and 'Jack of Hearts', 'Ssupersweet 4073', 'Ssupersweet 5344', and 'King of Hearts' had the most HH. 'Jack of Hearts' and 'Crimson Sweet' fruit were cut and evaluated in Spring 1993 at 5, 12, 19, 26, and 33 days after anthesis. Incidence of $\mathrm{HH}$ was low in 5- and 12-day-old fruit, increased in fruit that were 19 or 26 days old, and did not increase in older fruit. About one-third of fruit from both varieties had some HH. Among the seven entries in another test in Spring 1993, 'Tri-X-313' had the least HH and 'Crimson Sweet', 'Jack of Hearts', and 'Jubilee II' had the most.
INFLUENCEOF SEVERAL NONDEGRADABLEMULCHES AND ONE BIODEGRADABLE MULCH ON YIELD OF CRIMSON SWEET WATERMELON

Mack Wilson*, Victor Khan, and Clauzell Stevens, Department of Agriculture, Southeast Missouri State University, Cape Girardeau, MO 63701; and George W. Carver Agricultural Experiment Station, Tuskegee University, Tuskegee, AL 36088

An experiment was conducted to determine the influence of several synthetic mulches and one biodegradable mulch on the yield of 'Crimson Sweet' watermelons. The experimental design was a randomized block design using VisPore rowcover and various mulches. The results showed that using brown mulch resulted in a significant increase in marketable numbers of watermelons. Total yield of watermelons showed significant row cover $\times$ mulches interaction. Higher yields were observed with brown mulch and VisPore rowcover. The total number of watermelons grown with mulches was significantly greater than the control.

\section{PRECISION SEEDING FOR PLANTING CAULIFLOWER TO A STAND}

R.P. Bracy*, R.L. Parish, and E.B. Moser, Louisiana State University Agricultural Center, Louisiana Agricultural Experiment Station, Hammond Research Station, 21549 Old Covington Highway, Hammond, LA 70403

Field studies were conducted in Fall 1991 and 1992 to determine if cauliflower (Brassica oleracea L. Botrytis Group) could be precision seeded to a stand without subsequent thinning and what the optimum seed spacing necessary to directly seed cauliflower to a stand. Seed spacings of 10,20, and $30 \mathrm{~cm}$ at one seed per hill and $30 \mathrm{~cm}$ at two seeds per hill were evaluated for effect on yield, head weight, plant population, and early harvest percentage. As evaluated in the laboratory, seeder precision (accuracy) was good with regard to seed counts and spacing measurements at the various seed spacings. Seeder precision evaluated in the field varied in distribution patterns among seed spacings and years. Cauliflower was successfully precision seeded to a stand without thinning during 2 years of fall plantings. Cauliflower directly seeded at one seed per hill and a $20-\mathrm{cm}$ spacing produced total and average head weights similar to cauliflower seeded $10 \mathrm{~cm}$ apart and thinned to $30 \mathrm{~cm}$ - the seeding method currently used by some commercial operators.

\section{COMPARATIVE YIELD OFFIVE SWEETPOTATOCULTIVARS PLANTED IN SINGLE AND DOUBLE ROWS}

V.A. Khan*, C. Stevens, M.A. Wilson, J.Y. Lu, and E.G. Rhoden, George Washington Carver Agricultural Experiment Station, Tuskegee University, Tuskegee Institute, AL 36088; and D.J. Collins and J.E. Brown, Department of Plant Pathology and Horticulture, Alabama Experiment Station, Auburn University, Auburn, AL 36849

In 1994, a study was conducted in split-plot design to determine the effect single- and double-row plantings would have on the yield of five sweetpotato cultivars. 'TU-1892', 'Carver', 'Jewel', 'TU-82-155', and 'Georgia Jet' were planted on a raised shaped bed 2 feet wide. All recommended fertilizers were banded in the center of the bed and plants then were placed 6 inches away on both sides of this band for the double rows; single rows consisted of plants placed only on one side of the fertilizer band. Plants were spaced 12 inches apart within rows, and the rate of fertilizer used for single and double rows was the recommended rate for single rows. All plots were sidedressed with an additional $80 \mathrm{lbs} / \mathrm{acre}$ of $\mathrm{K}$ at the time of flowering. Marketable yield data showed that double-row planting of 'Jewel', 'TU-82-155', and 'TU-1892' resulted in 36\%, 38\%, and 33\% significant increase in yield, respectively, compared to single-row plantings. Double-row planting also significantly increased the yield of U.S. no. 1 'TU-82155', 'Jewel', and 'Carver' sweetpotatoes by $40 \%, 43 \%$, and $19 \%$, respectively. All cultivars used in the study showed a significant increase in canners yield when planted in double vs. single rows. The results also indicated that 'TU-1892', 'Jewel', and 'TU-82-155' may be more efficient in fertilizer use because higher yields were obtained in double-row plantings at the single-row fertilizer rates without the additional application of fertilizers. 
FIELD DIAGNOSTIC TOOLS FOR ESTIMATING NITROGEN NEEDS FOR FRESH-MARKET TOMATOES IN KENTUCKY

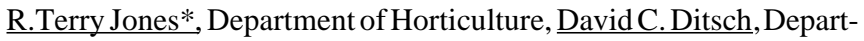
ment of Agronomy, University of Kentucky Robinson Substation, Quicksand, KY 41363-9007

In Kentucky, fresh-market tomato production is a 3-million-dollar crop involving 405 to 486 ha. During the 1980s, on-farm demonstrations showed yields and grower returns increased when intensive production practices were followed. Fertigation recommendations were based on a $1 \mathrm{~N}: 2 \mathrm{~K}$ ratio with a total of $225 \mathrm{~kg}$ N/ha. Symptoms of $\mathrm{Mg}$ deficiency and blossom-end rot sometimes were seen, and we were concerned about potentially high fertilizer concentrations in the plant root zone. Farm fertility trials (1992 to 1994) showed no yield response to applied $\mathrm{N}$ rates between 101 and $393 \mathrm{~kg} \cdot \mathrm{ha}^{-1}$. In 1993, a presidedress $\mathrm{N}$ test $(\mathrm{PSNT})\left(\mathrm{NO}_{3}+\mathrm{NH}_{4}-\mathrm{N}\right)$ indicated $131 \mathrm{~kg} \mathrm{~N} / \mathrm{ha}$ was available in the top $31 \mathrm{~cm}$ of soil. At the final tomato harvest, 343, 529, and $647 \mathrm{~kg} \mathrm{NO}_{3}+\mathrm{NH}_{4}-\mathrm{N}$ was measured in the top $46 \mathrm{~cm}$ of soil for the three $\mathrm{N}$ rates tested $(191,298$, and $391 \mathrm{~kg} \mathrm{~N} / \mathrm{ha})$. In 1994, the PSNT showed $86 \mathrm{~kg} \mathrm{NO}_{3}+\mathrm{NH}_{4}-\mathrm{N} /$ ha was present in the top $31 \mathrm{~cm}$ of soil. At final harvest 58, 124, and $157 \mathrm{~kg} \mathrm{NO}_{3}+\mathrm{NH}_{4}-\mathrm{N} / \mathrm{ha}$ was measured in the top $91 \mathrm{~cm}$ of soil for the 140,225 , and $309 \mathrm{~kg} \mathrm{~N} / \mathrm{ha}$ applied. Tomato phenology vs. petiole $\mathrm{NO}_{3}-\mathrm{N}$ concentration showed that all three $\mathrm{N}$ levels gave similar values, with no clear distinction between petiole $\mathrm{NO}_{3}-\mathrm{N}$ and the $\mathrm{N}$ rates tested. Future tests need to include a zero applied $\mathrm{N}$ rate to determine if a predictable relationship exists between a PSNT or petiole $\mathrm{NO}_{3}-\mathrm{N}$ levels and a yield response to fertilizer $\mathrm{N}$.

TOMATOES AND CUCUMBERS ARE A GOOD COMBINATION FOR A DOUBLE-CROPPING SYSTEM.

H.Y. Hanna, Louisiana State University Agricultural Center, Red River Research Station, P.O. Box 8550, Bossier City, LA 71113

Several studies were conducted to determine the effect of using tomato (Lycopersicon esculentum Mill.) plant skeletons as a support for trellised cucumbers (Cucumis sativus L.) double-cropped with tomatoes. In addition, the effect of mulch color, drip irrigation, and root-knot nematodes on subsequent cucumber yield also were examined. The presence of tomato skeletons significantly reduced the total yield (U.S. Fancy, no. 1, and no. 2), but not the premium (U.S. Fancy, no. 1) yield of cucumbers. Black polyethylene mulch used for the previous tomato crop had no undesirable effect on cucumber yield compared to the white mulch. Drip irrigated cucumber using same tomato irrigation lines significantly increased cucumber yield compared to nonirrigated cucumber. Cucumbers planted after nematode resistant tomatoes produced significantly higher yields than cucumber planted after nematode-susceptible tomatoes.

COMPARISONS OF USING ELECTRIC POLLINATOR OR BOMBUS IMPATIENSFOR POLLINATING HYDROPONICALLY GROWN TOMATOES

Richard G. Snyder*, Mississippi State University, Truck Crops Research and Extension Center, P.O. Box 231, Crystal Springs, MS 39059

A successful greenhouse tomato crop depends on the optimization of several factors; among these factors are water, nutrition, and all facets of environmental control. Good pollination, however, is one of the most important requirements for the production of fruit of high yield and quality. Poor pollination causes fruit that are smaller, angular, or puffy, due to reduced seed numbers and poor gel fill in the locules. In Spring 1993, two $7.3 \times 29.3$ double plastic-covered greenhouses were used to compare the conventionally used electric pollinator to bumblebees for effective pollination; replicated variety trials were performed within each. In one greenhouse (12 replications, RCBD), 'Trust' performed better than 'Caruso' in yield and quality, although it was smaller in fruit size. In the other greenhouse (four replications, RCBD), 'Match' and 'Switch' were better than all others ('Belmondo', 'Capello', 'Laura', and 'Rakata') for most yield and quality variables. Means across varieties were similar for the two pollination techniques, with marketable weights identical. For gutterconnected greenhouse ranges of 0.1 ha or larger, bumblebees are an economically viable option for pollinating hydroponically grown tomatoes.
IMPROVING QUALITY OF CONTAINER-GROWN PEPPER TRANSPLANTS THROUGH FERTILITY MANIPULATION

Darbie M. Granberry* and William Terry Kelly, Rural Development Center, P.O. Box 1209, Tifton, GA 31793

During summer in southern Georgia, greenhouses often reach or exceed 49C. Subsequently, transplants grown in these houses tend to exceed optimum height. To determine effects of $\mathrm{N}$ and $\mathrm{P}$ fertility levels on pepper (Capsicum annuum) transplant growth, applications of nutrient solutions with 58, 12 , and $0 \mathrm{ppm} \mathrm{N}$ and 114, 57, and $0 \mathrm{ppm} \mathrm{P}_{2} \mathrm{O}_{5}$ were applied to recently emerged Capistrano bell pepper beginning 12 Aug. 1994. Plants were grown in polystyrene flats using a commercial noncharged artificial soil mix. Nutrient solutions were applied as needed to maintain adequate moisture until $31 \mathrm{Aug}$., except for two treatments that received only water after 22 Aug. Data were taken on 22 and 31 Aug. With 58 ppm N, 0 P decreased plant height, leaf count, leaf area, and plant weight. Higher $\mathrm{N}$ increased plant height, ratings of intact root plugs and washed roots, stem diameter, leaf count, leaf area, and plant weight. At $12 \mathrm{ppm} \mathrm{N}, \mathrm{P}$ had no significant effect on transplant growth. Withholding fertilizer the final week reduced plant height, ratings of intact root plugs, stem diameter, number of leaves, leaf area, and plant weight.

\section{EFFECTS OF ROWCOVER AND TRANSPLANT METHODS ON SUMMER SQUASH PRODUCTION}

J.E. Brown* and R.P Yates, Department of Horticulture, Auburn University, AL 36949; and C. Stevens and V.A. Khan, Milbanks Hall, Division of Agricultural Sciences, Tuskegee University, AL 36088

Effects of planting methods and rowcover on the production of yellow crookneck squash, Cucurbita pepo L. var. melopepo Alef., were evaluated over 2 years at the E.V. Smith Research Center, Shorter, Ala. Summer squash was direct-seeded or transplanted in the field with or without black plastic mulch and grown with or without rowcover. Yield of transplanted squash was significantly increased over the same squash direct-seeded. Neither plastic mulch nor rowcover had an effect on summer squash production. Transplants matured 8 to 10 days earlier than the direct-seeded plants.

\section{CUCUMBER YIELD RESPONSES TO RAW AND PROCESSED POULTRY LITTER}

Warren Roberts*, Jim Duthie, and Julia Whitworth, Wes Watkins Agricultural Research and Extension Center, Oklahoma State University, Box 128, Lane, OK 74555

Large amounts of poultry litter are produced in eastern Oklahoma. Nitrate leaching from stockpiled litter can contaminate water supplies. Poultry producers need additional land for disposal of litter. Poultry litter can be a good fertilizer because it usually contains $2 \%$ to $3 \% \mathrm{~N}$, $\mathrm{P}_{2} \mathrm{O}_{5}$, and $\mathrm{K}_{2} \mathrm{O}$. The ratio of $\mathrm{N}: \mathrm{P}: \mathrm{K}$ is about $1: 1: 1$. Soils in the area often need fertilizer with about a 1:1:2 ratio for cucumber production. This study was established to determine if poultry litter alone could be used to supply all of the nutrients needed for cucumber production, and if excess nutrients would be detrimental to crop growth. Treatments consisted of two rates of raw poultry litter, two rates of composted litter, and synthetic fertilizer applied in either a single or a split application. Treatments ranged from 112, 112, and $224 \mathrm{~kg} \cdot \mathrm{ha}^{-1}$. The greatest yield came from the highest rate of poultry litter. Composted litter did not yield more than raw litter. Splitting the application of synthetic fertilizer did not improve yields over that of a single application of the same material.

\section{RHIZOBIUM COMPETITION IN ANTIGUAN SOILS: STRAIN ISOLATION}

Dyremple B. Marsh* and Lurline E. Marsh, Department of Agriculture, Lincoln University, Jefferson City, MO 65101; and Brian Cooper, CARDI, St. Johns, Antigua, West Indies.

The enzyme-linked immunosorbent assay was used to determine the competitive ability of three Rhizobium strains introduced into Antiguan soil. Strain-specific antisera were prepared against each strain. Field experiments were conducted in Antigua using Rhizobium strains USDA 3384, USDA 3473, and USDA 3474 as a peat-base inoculant and pigeon pea as the test crop. Nodules from the respective 
treatments were removed and prepared for ELISA studies. There was cross reactivity between the antisera, but it was greatly reduced or eliminated by repeat adsorption with the cells of the cross-reacting strains. Nodule occupancy by plants treated with Rhizobium 3384, 3473 , and 3384 was $70 \%, 90 \%$, and $100 \%$, respectively. Nodules from 3384 and 3474 treated plants contained cells with no antigenic homology to the three antisera. We concluded that these nodules were developed from indigenous Rhizobium strains found in Antiguan soils.

INFLUENCE OF FLOWER REMOVAL ON TWO VARIETIES OF WHITE POTATOES AND THREE CULTIVARS OF SWEET POTATOES IN MISSOURI

Mack Wilson*, Victor Khan, and Clauzell Stevens, Department of Agriculture, Southeast Missouri State University, Cape Girardeau, MO 63701; and George W. Carver Agricultural Experiment Station and Tuskegee University, Tuskegee, AL 36088

A randomized design was conducted in 1994 to determine the effect of flower removal on yield of two potato and three sweetpotato cultivars. The results showed a three-way interaction with mean height of 'Atlantic' and 'Snowden' potatoes evaluated in this study. Total root numbers of the two potato cultivars were significantly greater when rowcovers were used. The yield of grade A sweetpotato cultivars was greater when flowers were removed. The yield and marketable yield of U.S. no. 1 sweet potatoes was significant when flowers were removed.

IMPLICATIONS OF THE CONTINUOUS USE OF PLANT NUTRIENT SOLUTION ON GROWTH OF SWEETPOTATO IN NFT Audrey A. Trotman*, P.P. David, D.G. Mortley, and D. Douglas, Tuskegee University, NASA Center for CELSS, Tuskegee Institute, AL 36088

In developing a nutrition management strategy that reduces the quantity of products entering the waste management stream, gaining an understanding of the patterns and fluctuations of nutrient levels and crop growth characteristics is essential. In a greenhouse study, 'TU82-155' sweetpotato was grown hydroponically for 120 days in three nutrient application-replenishment treatments: 1) REG- solution changed at 14-day intervals and volume allowed to fluctuate; 2) daily replenishment with $10 \times$ concentrate of a modified quarter Hoagland's solution $(\mathrm{MQH})$ or with water to regain set volume (30.4 liters) and maintain set point of electrical conductivity [(EC); 1050 to 1200 $\mu \mathrm{mho}]$; 3 ) daily replenishment with $10 \times$ concentrate of a modified half Hoagland's solution (MHH) or with water to regain the set volume and maintain the set point of EC. There were no statistically significant differences among nutrient application protocols for storage root count, fresh and dry weights, and percent dry matter. The $\mathrm{MHH}$ treatment consistently yielded significantly higher leaf biomass and pencil roots ( $>1 \mathrm{~mm}$ in diameter), indicating a higher potential for increased storage root yield. A nutrient application protocol using treatment 2 has potential for reduced waste production if used in hydroponic sweetpotato production. The plants from the MQH treatment initiated vegetative buds at a significantly later date than in the other treatments and generally showed evidence of suppressed plant development.

EFFECT OF DURATION OF STORING VINE CUTTINGS ON YIELD OF SWEETPOTATOES GROWN IN NFT

Jennifer L. Seminara*. Desmond G. Mortley, Philip A. Loretan, and Beverly Smith, George Washington Carver Agricultural Experiment Station, Tuskegee University, Tuskegee, AL 36088

Two trials were conducted to determine the effect of duration of storing vine cuttings on yield of sweetpotatoes grown under greenhouse conditions in nutrient film technique. TI-155 sweetpotato [Ipomoea batatas (L). Lam.] vine cuttings with leaves removed were stored at room temperature in an open basket for $0,3,5$, and 7 days before planting in a complete randomized design with two replications. A modified half Hoagland's nutrient solution was used. Nutrient solution $\mathrm{pH}$ was maintained between 5.5 and 6.0 and changed every 2 weeks. Salinity, electrical conductivity, and solution temperature were monitored at regular intervals. Results show a trend toward increased percent dry matter as storage duration increased. Storing vine cuttings for 5 days produced the highest yield of storage root fresh and dry weights. Foliage fresh and dry weights were not influenced by preplanting treatments.

INFLUENCE OF ROOT ZONE TEMPERATURE ON GROWTH, YIELD, AND PHENOLOGY OF SWEETPOTATOES GROWN IN NFT

Philip A. Loretan, Fred A. Avicki, Desmond G. Mortley*, and Wiletha Horton, George Washington Carver Agricultural Experiment Station, Tuskegee University, Tuskegee, AL 36088

A cooling system using the principles of heat transfer was designed to provide a temperature difference of $6 \mathrm{C}$ between root and shoot zones and to study the effect of this difference on growth, yield, and phenology of 'TI-155' sweetpotato [Ipomoea batatas (L.) Lam.] grown using the nutrient film technique in a greenhouse. Treatments were temperature control (20C) and variable temperature (26C) in a randomized complete-block design with two replications. A modified half Hoagland's nutrient solution with a $1 \mathrm{~N}: 2.4 \mathrm{~K}$ ratio was used and was changed every 2 weeks. Nutrient solution $\mathrm{pH}$ was maintained between 5.5 and 6 , and electrical conductivity, salinity, and solution temperature were monitored at regular intervals. Storage root fresh and dry weights (except for fibrous root dry weight) and foliage fresh and dry weights were not significantly influenced by root zone temperature. Leaf expansion rate and vine length were lower for root zone temperature control plants; stomatal conductance, transpiration, and leaf unfolding rates were similar for both treatments.

EFFECTS OF WINTER COVER CROPS AND N APPLICATIONS ON VEGETABLE CROP PRODUCTION SYSTEMS

K.M. Batal*, M.R. Hall, and D.M. Granberry, Horticulture Department, University of Georgia, Tifton, Ga.; J.T. Garrett, D.R. Decoteau, and R.T. Dufault, Horticulture Department, Clemson University, Clemson, S.C.; G.D. Hoyt, Department of Soil Science, and T.C. Gilsanz, J.M. Davis, and D.C. Sanders, Horticulture Department, North Carolina State University, Raleigh, N.C.

A vegetable production system using winter cover crops and $\mathrm{N}$ rates was evaluated for several years in Georgia, South Carolina, and North Carolina. Snap bean, cucumber, tomato, potato, and sweetpotato crops were tested at different locations. Cover crop plots produced higher yields and better quality in all locations as seasons progressed over 4 years. Soil $\mathrm{N}$ levels in fallow, wheat, and clover plots were similar at initiation, but $\mathrm{N}$ gradually increased in clover plots in successive years. Yield and quality of root crops improved with Crimson clover without $\mathrm{N}$ applications compared to fallow plots with $60 \mathrm{~kg} \mathrm{~N} / \mathrm{ha}$. Effects on yield and tuber size are discussed. Nitrate and $\mathrm{NH}_{4}-\mathrm{N}$ in the soil profile from 15 - to $150-\mathrm{cm}$ depth were monitored at all locations. Nitrogen availability, depletion, and leaching below the root zone were determined. At low $\mathrm{N}$ rate, clover plots had slightly higher $\mathrm{NO}_{3}$ in the soil profile; however, at high $\mathrm{N}$ rate, $\mathrm{N}$ supply by clover was not as critical, and $\mathrm{N}$ leaching was detected at much lower depths than at low $\mathrm{N}$ rates.

\section{COVER CROPS AND PEST MANAGEMENT}

S.C. Phatak*, D.R. Sumner, R.B. Chalfant, J.D. Gay, L.D. Chandler, R.L Bugg, and K.E. Brunson, University of Georgia, Coastal Plain Experiment Station, Tifton, GA 31793-0748

Cover crops relay-cropped with vegetables with conservation tillage were compared with fallow conventional production for 10 years. Conservation till-relay received no pesticide and only onequarter the recommended fertilizers. Winter cover provided significantly better weed control than conventional. Weed problems in relay occurred only in the rows where vegetables were planted. Legume winter covers increased soilborne organisms but did not influence root disease severity or postemergence damping-off. Thrips, aphids, and whiteflies were most frequent. These pests remained below the economic threshold with winter cover crop-relay. However, infestation of these pests and Colorado potato beetles was severe in conventional plots. Winter cover crops provided habitat for more than 14 beneficial insects. 


\section{Fruit Science}

CHEMICAL THINNING OF 'SURECROP' PEACH WITH LATRON AG-98 SURFACTANT

A.W. Caylor*, W.A. Dozier Jr., Department of Horticulture, and J. $\underline{\text { Pitts, Chilton Area Horticulture Substation, Alabama Agricultural }}$ Experiment Station, Auburn University, AL 36849

Latron AG-98 (formerly named Triton AG-98) was applied to 8year-old 'Surecrop' peach trees on Lovell rootstock at 0\%, 2\%, 4\%, and 6\% (v/v) on 13 Mar. 1990 and 1992 and 28 Mar. 1991. Our objective was to determine the effect Latron AG-98 had on percentage of blossoms removed, fruit set, total fruit count and yield, and marketable fruit weight. The percentage of blossoms removed increased with increasing rates of Latron AG- 98 . The $4 \%$ and $6 \%$ rates removed the greatest percentage of blooms in all 3 years. The number of fruit per $50 \mathrm{~cm}$ of shoot length, number of fruit removed by hand-thinning, percent fruit set, total fruit number, and total fruit yield decreased with increasing rates of Latron AG-98 in 1990 and 1992 but not in 1991. The marketable fruit weight increased with increasing rates of Latron AG98 in 1990 and 1992 but not in 1991. Latron AG-98 was not effective in 1991 because of a 2-day delay in application. Latron AG-98 was effective in removing blossoms from 'Surecrop' peach at all three rates. However, the $4 \%$ and $6 \%$ rates reduced the yields below a commercially acceptable level. The $2 \%$ rate of Latron AG- 98 could be useful as a tool to reduce the labor required to hand-thin peaches.

TIMING APPLICATION OF HYDROGEN CYANAMIDE (DORMEX) TO PEACH TREES USING A MODIFIED CHILLING MODEL

Arlie A. Powell* and Karl Harker, Department of Horticulture and National Weather Service, Auburn University, AL 36849

This multifaceted study was conducted over the past 6 years in Alabama to determine the efficacy of using hydrogen cyanamide to replace lack of chilling in peaches and to develop a working chilling model to allow proper timing of application. Several timings $(0 \%$, $25 \%, 50 \%$, and $75 \%$ chilling accumulation) for each chilling level and rates $(0 \%, 0.5 \%, 1.0 \%$, and $2.0 \% \mathrm{v} / \mathrm{v}$ of $50 \%$ hydrogen cyanamide) were evaluated in commercial orchards using replicated studies. It was determined that for Dormex to be effective, $60 \%$ to $65 \%$ of chilling for the cultivar involved must be accumulated, accompanied by no bud activity beyond bud swell. Rates of $0.5 \%$ and $1 \% \mathrm{v} / \mathrm{v}$ of $50 \%$ work well with the latter preferred. A computer chilling model was developed to assist growers with proper timing of application.

\section{GIBBERELLIC ACID ENHANCES FRUIT SET OF PHYSICALLY} DAMAGED BLUEBERRY FLOWERS

Gerard Krewer*, Tifton; Scott NeSmith, Griffin; Mark Rieger, Athens; and Ben Mullinix, Statistical Services, Department of Horticulture, Coastal Plain Experiment Station, Tifton, GA 31793

Rabbiteye blueberry (Vaccinium ashei R.) flowers often suffer slight freeze damage that prevents fertilization and fruit development. To determine if gibberellic acid $\left(\mathrm{GA}_{3}\right)$ might be useful in rescuing freeze-damaged flowers the following treatments were applied before anthesis to two cultivars at different locations: 1) undamaged control, 2) approximately two-thirds of the corolla and most of the style removed, 3) approximately half of the style removed, and 4) ovules lanced with an insect pin by driving it through the equator of the undeveloped berry until the point came out the other side. Half the bushes were not sprayed, and half were sprayed with $\mathrm{GA}_{3}(312 \mathrm{ppm}$, v/v) the night following treatment. 'Climax' at Chula, Ga., had good fruit set for treatment 1 with and without $\mathrm{GA}_{3}(70 \%$ to $85 \%)$. Good fruit set also occurred for treatment 2,3 , and 4 where $\mathrm{GA}_{3}$ was applied $(47 \%$ to $54 \%$ ), but poor fruit set without $\mathrm{GA}_{3}(4 \%$ to $16 \%)$. 'Tifblue' at Chula had significantly better fruit set for treatment 1 with $\mathrm{GA}_{3}(54 \%$ vs. $27 \%$ ). Excellent fruit set occurred for treatment 2, 3, and 4 where $\mathrm{GA}_{3}$ was applied ( $81 \%$ to $96 \%$ ), and poor fruit set without $\mathrm{GA}_{3}(6 \%$ to $7 \%)$.
'Tifblue' fruit set by $\mathrm{GA}_{3}$ sized better than 'Climax' fruit set by $\mathrm{GA}_{3}$. The experiments provide corroborative evidence that flowers that have suffered freeze damage to the stigma, style, corolla, and perhaps ovules can be set with $\mathrm{GA}_{3}$.

\section{FLOWER BUD HARDINESS OF SOUTHERN HIGHBUSHBLUE- BERRY CULTIVARS}

John R. Clark and Robert Bourne, Department of Horticulture, University of Arkansas, Fayetteville, AR 72701

The southern highbush blueberry (Vaccinium spp.) 'Blueridge', 'Cape Fear', 'Cooper', 'Georgiagem', 'Gulf Coast', and 'O'Neal'; the rabbiteye (V.ashei Reade) 'Climax'; and the highbush (V.corymbosum L.) 'Bluecrop' were evaluated for ovary damage following exposure of flower buds to 0 to 30C in a programmable freezer in Dec. 1993 and Jan. and Feb. 1994. The plants sampled were growing at the Univ. of Arkansas Fruit Substation, Clarksville. Damage was based on oxidative browning of the ovaries following an incubation period after removal from the freezer. With the exception of 'Climax', a minimum temperature of $-15 \mathrm{C}$ was required before bud damage was sufficient enough to differentiate among cultivars. All southern highbush cultivars and 'Bluecrop' had superior hardiness compared to 'Climax' at $15 \mathrm{C}$ in December, $-20 \mathrm{C}$ in January, and $-15 \mathrm{C}$ in February. Maximum hardiness of all cultivars was found in January. The hardier southern highbush cultivars were 'Cape Fear' and 'Blue Ridge'. Less hardy cultivars were 'Gulf Coast, 'Cooper', 'Georgiagem', and 'O'Neal', although the date of sampling affected the ranking of these clones for hardiness, especially for the February sample date. 'Bluecrop' was not consistently hardier than the hardier southern highbush cultivars, except at the February sample date.

\section{MIDGES MAY INJUREDRUPELETS AND REDUCE FRUIT-SET IN BLACKBERRIES}

Herbert D. Stiles and Paul J. Semtner, Southern Piedmont Agriculture Research and Extension Center, Virginia Polytechnic Institute and State University, Blackstone, VA 23824

Blackberry drupelet development is influenced by a number of agents (Ellis et al., 1991; Moore and Skirvin, 1990). We have observed poor drupelet-setting and 'nubbins' that were not attributable to common pests, such as tarnished plant bug or diseases. In seeking causes for such problems during 1986, we discovered tiny (diptera) larvae in unopened flower buds and newly opened blossoms of wildgrowing and domestic blackberries. Pistils and stamens of infested buds and blossoms showed signs of necrosis; injuries seemed worse in buds that contained more larvae. We confirmed relationships among bloom-time symptoms, drupelet setting, and fruit weight by tagging symptomatic and asymptomatic postanthesis blossoms on 22 May 1989. One week before the normal harvest season, symptomatic berries averaged $38 \mathrm{mg}$ and asymptomatic berries averaged $208 \mathrm{mg}$. Twelve symptomatic blossoms $(27 \%)$ produced no drupelets, 19 $(43 \%)$ produced one to 10 drupelets, and no symptomatic blossom yielded a normal berry. We devised or adapted larval collection and rearing apparatuses and procedures to obtain adult midges that were needed for taxonomic speciation of this new blackberry pest. During 1994, SEL identified resultant specimens as Contarinia agrimoniae Felt. This genus previously had not been recorded from Rubus buds, and little is known of C. agrimoniae habits, life cycle, etc. Additional studies are needed to identify procedures for management of $C$. agrimoniae.

\section{BLACKBERRY TRELLISES}

Herbert D. Stiles, Southern Piedmont Agriculture Research and Extension Center, Virginia Polytechnic Institute and State University, Blackstone, VA 23824

The Stiles bent fence (SBF) and single-sided shift trellis (SSST) are differently designed structures that function to isolate fruiting zones of summer-fruiting brambles on one side of the plant or row. The SBF and SSST are suited for use with cultivars that produce long, flexible, nonbranched canes. Summer pruning of stiff-caned, semi-erect types may encourage development of long, flexible lateral branches that are adaptable for training on these trellises; alternate-year cropping may 
be helpful where such pruning is necessary. The SSST operates on the same principles as our original single-sided trellis (SST), but the newer design is compatible with a broader range of commonly available construction materials. Construction plans will be published in a Virginia Agricultural Experiment Station Bulletin as soon as funds are made available. The SSST should allow greater manual harvest efficiency, more effective IPM, fewer yield losses to sunscald, compatibility with cultural management practices, lower costs of postharvest precooling, better condition of harvested fruit for maximum shelf life, and stronger prospects for machine harvesting of fresh-market brambles.

EVALUATION OF APPLE CULTIVARS FOR RESISTANCE TO FOUR BITTER ROT PATHOGENS

Yan Shi and C.R. Rom, Department of Horticulture and Forestry, University of Arkansas, AR 72701

Fifty apple cultivars and 30 Malus species were evaluated for resistance to four isolates of bitter rot pathogens, Colletotrichum gloeosporioides and C. acutatum, in controlled conditions. Fruit were wound-inoculated by placing $0.1 \mathrm{ml}$ of inoculum $(106$ conidia $/ \mathrm{ml})$ into puncture wounds ( $2 \mathrm{~mm}$ in diameter), and intact fruit were inoculated by spraying with inoculum. Inoculated fruit were incubated at 25 to $28 \mathrm{C}$ for 2 weeks. 'Golden Delicious' (susceptible) and 'Red Delicious' (resistant) were used as controls. Diseases were quantified by measuring lesion diameter, and disease severity was objectively rated. Relative lesion diameter and severity rating were calculated as $[\mathrm{X} \times$ $100 / R D-100]$ and $(X-R D) \times 100 / 7(X=$ parameter of given cultivar or species, $\mathrm{RD}=$ parameter of 'Red Delicious') to determine relative resistance. Conclusions were as follows: 1) different levels of resistance were identified in apple cultivars and Malus species and also were detected within 'Golden Delicious' and 'Red Delicious' types; 2) 'Jonagold', 'Oregon Spur II', 'Spartan', 'Melrose', 'Red Cort', 'Jonafree', 'VPI-9', and 'Red Delicious showed good relative resistant; 3) M. halliana, angustifolia, prunifolia, sylvestris, and fusca were more resistant than 'Delicious'; 4) M. angustifolia was immune to two isolates of C. acutatum.

THE EFFECT OF FIVE PREPLANT TREATMENTS ON THE EARLY PERFORMANCE OF PEACH ON A REPLANT SITE

Curt R. Rom*, B. Blackburn, and R. Bourne, Department of Horticulture, University of Arkansas, Fayetteville, AR 72701

The growth and productivity of 'Redhaven'/Lovell peach during the first 3 years in a replant site was evaluated after planting in one of five preplant treatments. Treatments (trt) were 1) nontreated control (CK), 2) killed fescue (F), 3) soybean rotation (L), 4) summer solarization (SOL), and 5) methyl bromide fumigation (FUM). An orchard was removed from the experimental site in Spring 1991 before establishments of treatments. In June 1991, a tall fescue (K-31), soybeans, or mustard, and cabbage were sown in trt plots 2,3 , and 4, respectively. In July, trt 4 was covered with clear, 4-mil plastic sheeting for 90 days. In October, trt 5 was fumigated with methyl bromide under a 4-mil plastic sheet. Trees were planted in Spring 1992. Soil characteristics, weed populations, and tree growth and productivity were measured in the first three seasons after planting. FUM significantly reduced weed density into the third season. SOL plots had the highest weed density in years 2 and 3. TCSA, yield, and yield efficiency of FUM trees were significantly larger than CK. Trees in F or SOL had significantly lower yields.

\section{BREEDING FOR RESISTANCE TO PLUM LEAF SCALD}

J.D. Norton*, G.E. Boyhan, and B. Tangsukkasemsan, Department of Horticulture, Auburn University, AL 36849

Plum leaf scald (PLS) caused by the organism Xylella fastidiosa is one of the most serious diseases of plum. After $X$. fastidiosa was identified as the causal agent for PLS, a feral source (Starcher no. 1) was used extensively in the breeding program. Microscopic (phase contrast) examinations of vacuum extracts and petiole squashes and later ELISA were used to determine PLS infection and later were correlated with a rating index for PLS and tree longevity. Cultivars, species, and their progeny, including Prunus americana, P. angustifolia,
P. cerasifera, $P$. munsoniana, $P$. salicina, $P$. simoni, $P$. bullata, and $P$. triflora were evaluated. Observations indicate that resistance is heritable and controlled by recessive genes. ELISA and visual observation indicated that an Auburn Univ. seedling (CD 122) was free from this disease.

\section{EFFECT OF ROOTSTOCK ON LONGEVITY AND FRUIT AND TREE CHARACTERISTICS OF PLUM}

J.D. Norton, G.E. Boyhan, and J.A. Pitts, Department of Horticulture, Auburn University, AL 36849

The dwarfing characteristics of St. Julien and Pixy rootstocks as measured by shoot growth and trunk cross-sectional area (TCSA) was evident. Tree survival was significantly reduced after 3 years on Nemaguard and Pixy rootstocks. None of the elements measured by foliar nutrient analysis were below the minimum for plums; however, significant multiple regression equations for total shoot growth, TCSA, and survivability were evident with $R^{2}$ of $\approx 0.30$ in all three cases.

\section{WATER QUALITY AS A POSSIBLE LIMITING FACTOR IN LOUISIANA MAYHAW PRODUCTION}

G.A. Picchioni*, Department of Agricultural Sciences, Louisiana Tech University, Ruston, LA 71272; and C.E. Johnson, Department of Horticulture, Louisiana State University, Baton Rouge, LA 70803

Ground water salinity is a major concern for crop diversification in Louisiana where mayhaw (Crataegus opaca) is being considered as a new fruit crop. Its saline resistance is unknown; thus, we evaluated it in greenhouse conditions. One-year-old seedlings were irrigated with tap water, $10 \mathrm{~mm} \mathrm{NaCl}\left(+2 \mathrm{~mm} \mathrm{CaC}_{12}\right)$, and $25 \mathrm{~mm} \mathrm{NaCl}$ (+5 mm $\mathrm{CaC}_{12}$ ) for 9 weeks. Leaf and stem dry matter accumulation were reduced by an average of $80 \%$ and $60 \%$ below controls, respectively, in seedlings irrigated with $25 \mathrm{~mm} \mathrm{NaCl}$. The fresh weight : dry weight ratios of stems and roots also were reduced by $25 \mathrm{~mm} \mathrm{NaCl}$ (15\% and $28 \%$ below controls, respectively). Notably smaller leaf growth suppression occurred when $25 \mathrm{~mm} \mathrm{NaCl}$ was supplemented with $5 \mathrm{~mm}$ $\mathrm{CaC}_{12}$ compared to $25 \mathrm{~mm} \mathrm{NaCl}$ in the absence of $\mathrm{CaC}_{12}$. The fact that $\mathrm{CaC}_{12}$ partially reversed the leaf growth inhibition may indicate that $\mathrm{Ca}$ fertilization could be of benefit for mayhaw orchards relying on saline ground water.

\section{PATTERNS OF ROOTSTOCK USAGE IN THE PECAN INDUS- TRY}

L.J. Grauke* and Tommy E. Thompson, U.S. Department of Agriculture, Agricultural Research Service Pecan Breeding and Genetics, Somerville, TX 77879

The commercial pecan [Carya illinoinensis (Wangenh.) K. Koch] nursery industry relies on open-pollinated seed for rootstock production. Current choice of seedstocks by commercial pecan nurserymen was surveyed by telephone. Nurseries were called if they appeared in the directory used for the 1994 release of 'Navaho'. Factors influencing the choice of seedstock include seed availability, nut fill, nut size, nut shape, seedling vigor, stand uniformity, and root characteristics. Local availability is important in the choice of seedstock. Those who harvest from their own trees usually credit the seedstock with other valuable characteristics, such as improved germination or vigor. Those who purchase seed usually target a preferred seedstocks for particular reasons but plant available seed in its absence. Well-filled nuts are recognized as being important for good germination. Small nuts are often preferred, especially when seed is purchased because more nuts per pound increases potential production. Round nuts are generally preferred over long nuts due to improved performance in some mechanical planters. Distinct regional preferences are apparent in the choice of seedstocks. Regionally preferred seedstock selections are generally validated by a survey of the research literature. Patterns of selection are consistent with climatic and geographic constraints. Tree procurement patterns have changed: many small nurseries have gone out of business, many large nurseries transport trees far from the nursery for sales, and quarantine restrictions have altered procurement patterns in Arizona. Recommendations are made to nurserymen, pecan growers, and researchers concerning continued progress toward improving regionally adapted pecan rootstocks through seedstock selection. 
PECAN KERNEL COLOR: STANDARDS USING MUNSELL COLOR CHIPS

Tommy E. Thompson*, L.J. Grauke, and E.F. Young, Jr., Pecan Genetics and Breeding Research, Agricultural Research Service, U.S. Department of Agriculture, Route 2, Box 133, Somerville, TX 77879

The Munsell Color System was used to study pecan [Carya illinoinensis (Wangenh.) K. Koch] kernel colors and color changes for 21 clones, 11 locations, and five storage methods for nuts collected over 4 years. Hue readings ranged from 10.0 (10 red) to 22.5 (2.5 yellow). Value readings ranged from 2.0 to 8.0 , and chroma readings ranged from 1.0 to 8.0. A total of 91 classes (individual combinations of hue, value, and chroma) were needed to describe all kernel colors. Overall, one class 115.0/5/4 (hue/value/chroma)] accounted for 3979 of the 32,078 readings taken, and the 15 most common classes accounted for $80.7 \%$ of all the readings. This system of color determination was well-suited for pecan color determinations and continues to be used routinely as a part of our breeding and genetics program to define this important quality trait in pecan.

\section{METHODS OF CONTROLLING OVERCROWDING FOR PE- CANS}

Ray E. Worley*, Department of Horticulture, and Ben Mullinix, Department of Statistical and Computer Services, University of Georgia, Coastal Plain Experiment Station, Tifton GA 31793-0748

Treatments of control, selective limb pruning (SLP), tree thinning, $\mathrm{SLP}+12.24 \mathrm{~kg}$ paclobutrazol/ha, and SLP $+3.36 \mathrm{~kg}$ paclobutrazol $/ \mathrm{ha}$ were applied to 'Desirable', 'Western Schley', and 'Wichita' pecans for $>7$ years. Thinning increased yield per tree significantly for 'Desirable' but not for the other cultivars. Thinning did not increase yield per hectare during the study. Paclobutrazol application reduced terminal shoot growth but did not benefit yield or kernel quality. There was no significant benefit from SLP with or without paclobutrazol.

COMBINING LONG-TERM PRODUCTION CURVES OF SEVERAL PECAN TREES OF SAME CULTIVAR WHEN SLOPE ESTIMATES ARE NOT EQUAL AND VARIANCES ARE HETEROGENEOUS

Benjamin Mullinix*, Statistical and Computer Services, and Ray Worley, Department of Horticulture, Georgia Coastal Plain Experiment Station, Tifton, GA 31793-0748

Eleven 'Desirable' pecan trees with yield data for 22 to 47 years were selected from a database with data from three orchards. Cumulative yield were computed for each tree. Cumulative data was transformed using LOG10. Quadratic or cubic regression curves were fit for each tree and for all in a single analysis. In most cases, variances were not homogeneous among the 11 trees. Using the regression coefficients for each tree, an average of the five was made and appropriate standard errors were computed. Number of cases where homogeneity of variances were found increased. Younger trees benefiting from better orchard management had different variances than older trees moving across changing managements. LOG10-transformation tended to decrease variation, but variances were still heterogeneous.

\section{THE INFLUENCE OF YIELD ON FATTY ACID COMPOSITION} OF PECAN NUTS

J.B. Storey, L.J. Grauke*, Laurence Sistrunk, and Tommy E. Thompson, Department of Horticulture, Texas A\&M University, and U.S. Department of Agriculture, Agricultural Research Service, Pecan Breeding and Genetics, Somerville, TX 77879

Four cultivars of pecan [Carya illinoinensis (Wangenh.) K. Koch] were studied for 3 years to determine if variations in yield influence fatty acid composition of kernels. Trees used in the study are part of the U.S. Dept. of Agriculture, Agricultural Research Service Historical Block, a test orchard planted in randomized block design with four blocks, having one single-tree replication per block and containing 36 cultivars. Four trees of each of four cultivars ('Cheyenne', 'Mohawk', 'Pawnee', and 'Osage') were used in this test. Trees were in their 5th to 7th leaf from grafting and showed patterns of increasing yield over time for each cultivar. 'Osage' was earliest to mature nuts each year and produced nuts with the lowest linoleic acid content. 'Cheyenne' was latest to mature nuts and had nuts with the highest linoleic acid content. Oleic acid composition varied with yield in 'Osage' and 'Pawnee': as yield (kilogram/square decimeter trunk area) increased, oleic acid content decreased. Kernel color, as determined by a Hunter LabScan 5100 Spectrocolorimeter, varied in relation to fatty acid composition for 'Osage' and 'Pawnee': as oleic acid content increased, kernel lightness decreased. High oleic acid content and light kernel color are associated with high-quality pecans. The pattern of decreasing oleic acid content associated with increasing kernel lightness raises questions concerning the role kernel color evaluation should play in selecting high-quality pecan cultivars.

\section{Floriculture/Ornamentals}

MINIATURE POTTED ROSE PRODUCTION USING COMPOSTED POULTRY LITTER AS A MEDIA COMPONENT

Garry V. McDonald, H. Brent Pemberton, Marvin L. Baker, and Jo Mondier, Texas A\&M University Agricultural Research and Extension Center, P.O. Box E, Overton, TX 75684

Liners of Rosa 'MEIrutral' (=Red Sunblaze) were potted in 11.5$\mathrm{cm}$ pots using Fison's Sunshine Mix no. 2 amended with $0 \%, 10 \%$, $20 \%$, or $30 \%$ composted poultry litter (PL) by volume. Plants were grown for 3 weeks before cutting back to $5 \mathrm{~cm}$ for final forcing (shortcycle) and were fertilized with $200 \mathrm{mg}$ N/liter from 20N-8.9P-16.6K on a three feed and one leach schedule for the duration of the experiment. By flowering, plants growing in the 30\% PL media were dead or stunted. However, there was little difference in total number of flowers, days to flower, and root and shoot dry weight between the other treatments. Media pH rose from 6.6 to 7.4 and EC rose from 0.7 to 6 millimhos with increasing PL content. This result alone could explain the poor growth in the highest PL rate treatment. However, tissue N levels were supraoptimal for the $20 \%$ and $30 \%$ PL rates, and tissue $\mathrm{P}$ levels were excessive for all PL rates. If a high-quality source of composted PL is available, it could be used as a media component for potted rose production at rates $<20 \%$, but monitoring of $\mathrm{pH}$ and $\mathrm{EC}$ and modifying fertilization techniques may be necessary to ensure success.

THE EFFECTS OF PHOTOPERIOD AND TEMPERATURE ON FORCING OF OXALIS REGNELLII AND O. TRIANGULARIS

A.A. De Hertogh*, L. Gallitano, and K. Kim, Department of Horticultural Science, North Carolina State University, Raleigh, NC 276957609

In recent years, several physiological disorders of unknown origin have been observed on Oxalis regnellii and $O$. triangularis, two widely forced species. Therefore, an experiment was carried out in the NCSU Phytotron. The forcing temperatures were 18/14C, 22/18C, and 26/22C (day/night), and these temperatures were combined with 9-h and long day (3-h night break) photoperiods. In addition, two planting media (Metro 360 and Sunshine no. 4) were used. Control plants were grown under greenhouse conditions. With $O$. regnellii, leaf chlorosis and wrinkling were prevalent in the greenhouse. In the phytotron, the highest quality plants with the least amount of leaf disorders were produced under LD at 26/22C. No differences were obtained with the planting media. With $O$. triangularis, the highest quality plants with the least leaf disorders (bronzing and wrinkling) were grown in the phytotron at 26/22C. In addition, LD significantly enhanced flowering. Leaf disorders were prevalent in the greenhouse and enhanced with Sunshine no. 4.

ROOT PRUNING AND FERTILIZATION INFLUENCEGROWTH OF BAREROOT CORYLUS COLURNA

Patricia R. Knight*, James R. Harris, and Jody Fanelli, Department of Horticulture, Virginia Polytechnic Institute and State University, Blacksburg, VA 24061-0327

Bareroot Corylus colurna were grown in 7.5-liter containers from 11 Apr. until 27 June 1994. The growing medium was fritted clay. 
Fertility levels included no fertilization, 100 ppm N, or 200 ppm N. Plants were root pruned to remove none or one-quarter to one-half of the primary roots. Root pruning at any level resulted in decreased height, shoot, and root dry weights and number and length of new shoots. One-quarter primary root removal resulted in lower root: shoot ratios compared to plants that were unpruned. One-half primary root removal further reduced root : shoot ratios. One-half primary root removal also reduced total leaf area compared to unpruned controls. Fertilization at $200 \mathrm{ppm} \mathrm{N}$ increased leaf numbers and total leaf areas compared to plants receiving no fertilization.

REMEDIATION OF THE POLLUTANT CONTENT OF RUNOFF WATER FROM A CONTAINERIZED PLANT NURSERY

Jeanne A. Briggs*, Mellissa B. Riley, and Ted Whitwell, Department of Horticulture, Box 340375, Clemson University, Clemson, SC 29633-0375

The pesticides isoxaben, trifluralin, chlorpyrifos, and thiophanatemethyl were applied at recommended rates to a 4-ha growing bed at an operating container nursery. Runoff samples produced by overhead irrigation were collected from three waterways, 300 feet long $\times 6$ feet wide. The waterways were a sodded hybrid bermudagrass, a plantation of common cattails (Typha latifolia), and a gravel-clay waterway used as a reference. A 2-ha area drained into the sodded waterway, which flowed into the cattails, and a 2-ha bed flowed into the reference waterway. Samples were collected throughout the duration of runoff on day of treatment and at $1,2,8,15$, and 22 days after treatment. Runoff volumes were recorded over time as measured at weirs. Analysis was by HPLC following solid-phase extraction. Only isoxaben was detected at 2 days after treatment. Initial concentrations of all pesticides were lower in the vegetated waterways than in the reference.

EVALUATIONOFWATER HYACINTH [EICHORNIA CRASSIPES (MART.) SOLMS-LAMB] FOR THE REMOVAL OF NITROGEN IN NURSERY RUNOFF

Derald A. Harp* and Ed McWilliams, Department of Horticultural Sciences, Texas A\&M University, College Station, TX 77843

The ability of water hyacinth to remove $\mathrm{N}$ from nursery runoff was evaluated in two separate experiments. In Expt. 1, individual plants were placed in 10-liter ceramic containers with nutrient solutions with varying levels of $\mathrm{N}(0,1.5,3,6,12$, and $24 \mathrm{~mm})$. In Expt. 2, plants were placed in pools used to mimic runoff ponds. Pools were filled with 80 liters of reverse osmosis water, $2 \mathrm{~cm}$ of a native sandy loam, and either 48.03 or $24.015 \mathrm{~g}$ of $20-10-20$ Peters water-soluble fertilizer. Plants in ceramic containers had no significant difference in weight gain across treatments $(P<0.05)$. However, the $24 \mathrm{~mm}$ treatment did have significantly more $\mathrm{N}$ remaining in the solution than other treatment levels. Plants in the pool experiments exposed to $3.0 \mathrm{~mm} \mathrm{~N}$ had significant increases in number of new plants produced and total biomass production over those exposed to $1.5 \mathrm{~mm}$ N. No differences existed in the amount of time needed to remove $\mathrm{N}$ because $\mathrm{N}$ was undetectable after 18 to 23 days at 3 and $1.5 \mathrm{~mm}$.

HORTICULTURAL YOUTH EDUCATION: THE MISSING LINK Kathleen C. Ruppert*, Environmental Horticulture Department, University of Florida, Gainesville, FL 32611-0670

Most college professors spend little time helping youth (kindergarten to 12th grade) learn about horticulture, and the elementary and secondary schools seem to have created a dividing line between scientific concepts and practical life-long skills. Biology classes continue to emphasize the chemical processes of photosynthesis and deemphasize the nurturing, caring, dependability, responsibility, sense of accomplishment, and other life-long skills that can be obtained from growing plants. However, retail garden centers and chain stores are increasingly offering books and supplies on gardening and related activities for children. Seed companies market and package seeds just for children. Botanical gardens and arboretums are including youth horticultural activities as part of their on-going educational programs. The involvement of university educators in horticultural youth education can assist the "trickle up" theory to the parents of children along with affecting future voters. Take the first step to see what classroom horticultural materials are available in your state. Currently many teachers have an interest in learning more about horticulture but need educational materials. In addition, there is a large number of volunteers interested in this endeavor. Do your part and help develop accurate horticultural materials for these instructors to use in formal and informal educational settings.

DEVELOPMENT OF IRRIGATION AND FERTILIZATION BEST MANAGEMENT PRACTICES FOR CONTAINER NURSERIES.

Tom Yeager*, Environmental Horticulture Department, University of Florida, Gainesville, FL 32611; Donna Fare, Tennessee Tech, Cookeville, TN 38505; Charles Gilliam, Auburn University, Auburn University, AL 36849; and Alex Niemiera, Virginia Polytechnic Institute and State University, Blacksburg, VA 24061

More regulations have an impact on nursery industry today than 10 to 20 years ago, and additional regulations are likely in the future. In view of this, the southeastern nursery industry is taking proactive action by developing a handbook of irrigation and fertilization best management practices (BMP) for container nurseries. Using BMP would be voluntary but could "head off" additional regulations. Additionally, BMP would serve as guidelines for growers 1 ) attempting to be more environmentally friendly, 2) wanting to promote the fact they are environmentally friendly, and 3) dealing with a complaint from regulatory agencies. Our objective was to develop a BMP handbook that nursery managers could use to find answers quickly to management questions regarding irrigation and fertilization. The handbook was written by university horticulturists, but input and reviews were obtained from industry personnel, additional university personnel, and others associated with the nursery industry. The handbook will be distributed in late summer by the Southern Nurserymen's Association, Marietta, Ga.

THE SFASU ARBORETUM WOODY AND HERBACEOUS PLANT EVALUATION PROGRAM: PLANTS WITH PROMISE David Creech*, Department of Agriculture, P.O. Box 13000, Stephen F. Austin State University, Nacogdoches, TX 75962-3000

The mission of the SFASU Arboretum is to promote the conservation, selection, and use of the native plants of Texas and to encourage diversity in the urban landscape philosophy of the region. A decade since its inception, the 10 -acre arboretum features many uncommon, unusual, and difficult-to-find species and cultivars, many deserving greater use in the region. The living collection has been acquired through botanical gardens, arboretums, private collections, the nursery industry, and expeditions. The list of promising plants that have surfaced includes many that are not easily available in the trade. The issues involved in woody and herbaceous plant evaluation include computer mapping and record keeping constraints, the long-time frame for evaluation with many woody plants, and difficulties in propagation. The arboretums's plant acquisition policy and record keeping and computer mapping system is currently tracking more than 2500 taxa in the living collection. An overview of the first decade of plant performance and a strategic plan for acquisition, propagation, evaluation, distribution, and promotion are presented.

\section{USE OF SPANISH MOSS (TILLANDSIA USNEOIDES L.) AS AN} INDICATOR OF TRACE ELEMENTS IN URBAN AREAS

Ed McWilliams and Derald A. Harp*, Department of Horticultural Sciences, Texas A\&M University, College Station, TX 77843

Spanish moss (Tillandsia usneoides) samples were deployed at 36 locations in a $6 \times 6$-grid system in northeastern Texas during the summer months of 1989 and again in the winter months of 1990. Analytical methods, including inductively coupled plasma emission spectrometry (ICP) and neutron activation analysis (NAA), were used in analyzing samples for sulfur, selenium, arsenic, sodium, and aluminum. Concentrations of most elements in Spanish moss samples were much higher in summer than winter. The highest concentrations of sulfur were found in Van Zandt, Wood, Titus, and Bowie counties. These results suggest that on average sulfur stays in the region in which it was generated. Potassium and sodium were highly correlated with latitude and seem to originate from the Gulf of Mexico. 


\section{Postharvest/Biotechnology}

INDUCTION OF MEALINESS DURING SHORT-TERM STORAGE FOR A NOVEL PEACH GENOTYPE

Niels O. Maness* and Donna Chrz, Department of Horticulture and Landscape Architecture, Oklahoma State University, Stillwater, OK 74078; and Joseph C. Goffreda, Department of Horticulture, Cook College, Rutgers University, New Brunswick, NJ 08903

The peach mutation 'Stony Hard' confers a slow softening attribute to the fruit and also confers a highly reproducible predisposal of fruit to soften abnormally to a mealy texture. Induction of mealiness required continuous 48-hour $100-\mathrm{ppm}$ ethylene exposure. 'Stony Hard' fruit exposed to low ethylene concentrations (l ppm) or discontinuous $100 \mathrm{ppm}$ ethylene softened more rapidly than fruit exposed to ethylene-free air but to a normal texture. Ethylene treatment failed to induce mealiness in selections without the 'Stony Hard' gene. As quantitative methods for assessment of mealiness, mesocarp-extractable juice decreased, and buffer soluble solids and soluble polysaccharide galacturonic acid content increased for mealy fruit. 'Stony Hard' peach fruit represent the only known system in which the concentration and duration of exposure to ethylene can be used to manipulate softening and textural properties of the fruit. Supported by U.S. Dept. of Agriculture grant 93-34150-8409 and the Oklahoma Agricultural Experiment Station.

COMBINING SHRINKAGE CURVES FOR SEVERAL CUCUMBERS RECEIVING SAME-STORAGE TREATMENT WHEN SLOPES ARE NOT EQUAL AND VARIANCES ARE HETEROGENEOUS

Benjamin Mullinix* and Albert Purvis, Statistical and Computer Services and Department of Horticulture, Georgia Coastal Plain Experiment Station, Tifton, GA 31793-0748

Five 'Poinsett' cucumbers were selected at random for each treatment in a postharvest storage experiment. Each cucumber was weighed initially, covered by wax "E", and weighed each day afterwards for 9 days. Percentage loss was computed for each day. Quadratic regression curves were fit for each cucumber and for all in a single analysis. In most cases, variances were not homogeneous among the five cucumbers. Using the regression coefficients for each cucumber, an average of the five was made and appropriate standard errors were computed. Percent loss data was transformed using SQRT. The number of cases where homogeneity of variances were found increased. Mixture of large and small cucumbers by weight tended not to be homogeneous, whereas mixing of cucumbers of similar weights were improved with square-root transformation.

\section{PEROXIDASE ACTIVITY DIFFERS IN SWEET CORN GENO- TYPES}

J.K. Collins, U.S. Department of Agriculture, Agricultural Research Service, SCARL, Lane, OK 74555; C. Biles, East Central University, Ada, OK 74820; and E.V. Wann, and P. Perkins-Veazie, U.S. Department of Agriculture, Agricultural Research Service, SCARL, Lane, OK 74555

Increased peroxidase activity is used to predict development of offflavor in frozen sweet corn. However, peroxidase activity was not indicative of flavor changes in frozen supersweet (sh2) or sugar enhanced (sul/se) sweet corn genotypes. These results suggested an inactivation or absence of certain peroxidase isozymes. Frozen 'Florida Staysweet' (sh2), 'Merit' (sul), and 'Bodacious' (sul/se) kernels were cut from cobs after 0 and 12 months of storage. Proteins extracted from acetone powders were separated by isoelectric focusing (IEF) and Native-PAGE. Banding patterns differed according to cultivar and storage duration. All cultivars contained a peroxidase isozyme having a molecular weight of $99 \mathrm{kD}$ and $\mathrm{pI}$ of 4.5 . The sul/se and su 2 cultivars expressed an additional peroxidase band of $17.9 \mathrm{kD}$. An additional peroxidase isozyme (pI 5.0) appeared after 12 months of storage in the sul cultivar. This isozyme did not appear in sul/se or sh2 and is a possible marker for predicting off-flavor in corn. This isozyme may also catalyze off-flavor reactions in sul corn genotypes. Although changes in total peroxidase activity may not predict flavor loss in all genotypes, certain peroxidase isozymes may be useful in predicting and catalyzing off-flavor reactions in sul corn cultivars.

IMPLEMENTATION OF A HACCP IN A COMMERCIAL TOMATO PACKINGHOUSE: A MODEL FOR THE INDUSTRY

James W. Rushing, Coastal Research and Education Center, Clemson University, 2865 Savannah Highway, Charleston, SC 29414; and Frederick J. Angulo, Centers for Disease Control and Prevention, Department of Health and Human Services, 1600 Clifton Road North East, Altanta, GA 30333

In response to epidemiological studies that linked outbreaks of salmonellosis to consumption of raw tomatoes in 1991 and 1993, a model HACCP was designed and implemented in a commercial tomato packinghouse in South Carolina in 1994. Testing of tomato fruit and packinghouse water samples by $\mathrm{CDC}$ and by a private laboratory for the presence of Salmonella confirmed that the HACCP was effective in controlling the risk of contamination in the packinghouse. Critical control points are identified and application of this model HACCP to other fresh fruit and vegetable handling systems is proposed.

\section{INTERMITTENT WARMING DELAYS CHILLING INJURY IN OKRA}

P. Perkins-Veazie* and J.K. Collins, U.S. Department of Agriculture, Agricultural Research Service, South Central Agricultural Research Laboratory, Lane, OK 74555

Okra develops chilling injury after 4 to 5 days at $2 \mathrm{C}$ or 8 days at $5 \mathrm{C}$. Intermittent warming has prevented or delayed chilling injury in warm season crops. The purpose of this experiment was to find a way to prevent or delay chilling injury in okra. Field grown 'Annie Oakley', 'Blondy', and 'Clemson Spineless' okra pods were held constantly at 2,5 , or $10 \mathrm{C}$ or placed at $2 \mathrm{C}$ or $5 \mathrm{C}$ for 2 days followed by 2 days at $10 \mathrm{C}$ (2-10 and 5-10, respectively) then returned to their original temperature. After 8 days of storage, all boxes were placed at 20C for 1 day; color was measured with a colorimeter, and pods were rated subjectively for chilling injury. 'Annie Oakley' and 'Clemson Spineless' pods held at $2 \mathrm{C}$ were olive-green to brown; okra held at 2-10 was green and still marketable. Less chilling injury occurred to pods held at 5 and 5-10 compared to those at $2 \mathrm{C}$. Pods held at $2-10,5$, or 5-10 had injury after 8 to 10 days of storage compared to 5 days at $2 \mathrm{C}$. Although chilling injury could not be completely prevented in okra by intermittent warming, shelf life could be lengthened by cooling pods at $2 \mathrm{C}$ for no more than 2 days to eliminate field heat and reduce weight loss, followed by storage at a higher temperature.

REGENERATION OF COWPEA [VIGNA UNGUICULATA (L.) WALP.] FROM SEEDLING SHOOT APEX CALLUS

Jameel M. Al-Khayri*, Teddy E. Morelock, and Edwin J. Anderson, Departments of Plant Pathology and Horticulture, University of Arkansas, Fayetteville, AR 72701

Cowpea, or southernpea, is an important food legume that provides a source of high-quality protein, especially in the mature seeds. In the United States, industries exist to supply dry and processed seeds. Our aim is to develop a regeneration system for cowpea as a prerequisite for genetic engineering. Our objective was to examine the in vitro responses of shoot tips to growth regulators. Shoot tips isolated from in vitro-germinated seedlings ('Coronet') were cultured on MS medium containing 2,4-D at $0,0.01,0.1$, or $1 \mathrm{mg}^{\circ} \mathrm{liter}^{-1}$ and kinetin at 2.5, 5,10 , or $20 \mathrm{mg} \cdot \mathrm{liter}^{-1}$. Cultures were maintained at 12 -hour photoperiods and $24 \mathrm{C}$. Callus, shoots, and roots or combinations thereof developed depending on the treatment. Callus formed on $1 \mathrm{mg} 2,4-\mathrm{D} /$ liter, regardless of the kinetin level, but at $0.1 \mathrm{mg} 2,4-\mathrm{D} / \mathrm{liter}$ and 5 or $10 \mathrm{mg}$ kinetin/liter, shoots also grew. Callus, shoots, and roots developed on 2,4-D lower than $0.1 \mathrm{mg} \cdot \mathrm{liter}^{-1}$. Callus induced on $5 \mathrm{mg}$ kinetin/liter and $0.01 \mathrm{mg}$ 2,4-D/liter regenerated shoots on transfer to $5 \mathrm{mg}$ kinetin/liter and $0.1 \mathrm{mg}$ NAA/liter. This work may assist in the development of a micropropagation system for cowpea. 
OPTIMIZING RAPD MARKERS FOR ONION GENOMIC DNA ANALYSIS

Ruwanthi C. Wettashinghe* and Ellen B. Peffley, Department of Plant and Soil Sciences, Box 42122, Texas Tech University, Lubbock, TX 79409

Random amplified polymorphic DNA (RAPD) are genetic markers that facilitate selection in plant breeding. To obtain clear reproducible, and repeatable RAPD bands, four DNA extraction protocols and two Taq polymerases were compared using thirteen TG1015Y (Allium сера) genotypes. Protocols for DNA extraction followed those of a modified Tai and Tanksley, 1989 (PMBR); a modified Dellaporta et al., 1983 (PMBR); a modified Guillemunt et al., 1992 (PMBR); and extracted with a plant tissue DNA isolation kit from Gentra System (Minneapolis). The modified Guillemunt protocol was selected due to ease of extraction and cost effectiveness. Polymerases compared were Taq and Taq Stoffel fragment. Results are based on three separate amplifications and electrophoretic assays. PCR amplifications of Stoffel fragment produced more scorable and reproducible RAPD bands compared to bands produced using Taq polymerase.

\section{TRANSFORMATION OFONIONCALLUS VIA PARTICLE BOM- BARDMENT}

Ellen B. Peffley* and Melanie A. Hart, Department of Plant and Soil Science, Texas Tech University, Lubbock, TX 79409

Particle bombardment was investigated as a potential transformation method for onion. Seeds of Allium cepa 'TG 1015' were planted onto BDS medium and placed in a dark incubator at $25 \mathrm{C}$ for germination. Two to 3 weeks after the seeds were germinated, meristems ( 1 to $2 \mathrm{~mm}$ ) were excised and placed onto BDS medium containing $2 \mathrm{mg}$ 2,4-D/liter for callus initiation. Callus was transferred monthly onto fresh BDS medium containing 2,4-D until bombardment. The reporter gene for B-glucuronidase (GUS) expression was used to assess efficiency of gene delivery in all particle bombardments. Characteristics examined were target distance and helium pressure (particle velocity). Tissues were subjected to the 5-bromo-4-chloro-3-indoyl-B-D-glucuronide (xgluc) test for detection of GUS activity. Measurements were taken on particle dispersion as affected by target distance and helium pressure. GUS expression was detected in putatively transformed tissues.

POTENTIALFOR HIBISCUS CANNABINUSIMPROVEMENT VIA SOMACLONAL VARIATION

Nancy A. Reichert* and Brian S. Baldwin, Department of Plant and Soil Sciences, Mississippi State University, Box 9555, Mississippi State, MS 39762

Adventitious regeneration protocols were developed for kenaf (Hibiscus cannabinus $\mathrm{L}$.) using leaf tissue. Regenerants $\left(\mathrm{R}_{0}\right)$ of three cultivars and $R_{1}$ progeny from one cultivar were grown in greenhouse and field trials for assessment of various growth characteristics. $R_{0}$ regenerants differed from control plants in the variety of stem colors displayed. On germination, a proportion of $\mathrm{R}_{1}$ seedlings were chlorophyll-deficient (albinos), whereas no control seedlings contained that mutation. Flowering date also was earlier in the $\mathrm{R}_{1}$ plants. The kenaf regeneration protocol also has been successful on $H$. syriacus (Althea, rose of Sharon), and other ornamental species are currently being evaluated. With kenaf data, the adventitious regeneration protocol potentially could be a useful tool for inducing mutations in various species of Hibiscus, including ornamentals.

AUXIN TYPE DURING INDUCTION AFFECTS PECAN SOMATIC EMBRYO DEVELOPMENT AND MORPHOLOGY

Hazel Y. Wetzstein* and Adriana P.M. Rodriguez, Department of Horticulture, Plant Science Building, University of Georgia, Athens, GA 30602-7273

Somatic embryogenic cultures of pecan (Carya illinoinensis) were induced on medium with either naphthaleneacetic acid (NAA) or 2,4dichlorophenoxyacetic acid (2,4-D). Percent embryogenesis, embryo development, and subsequent performance were assessed. Cultures induced on medium with NAA were more zygotic-like, with a higher frequency of embryos that had well-defined shoot apices. In contrast, cultures induced with 2,4-D exhibited more extensive callusing and more fused and/or abnormal embryos. Adjustment of the auxin used during induction may be a means of obtaining higher quality embryos, that have higher rates of conversion into plants.

MOLECULAR HYBRIDIZATION STUDIES IN ALLIUM

Usha S. Kallemuchikkal* and E.B. Peffley, Department of Plant and Soil Science, Texas Tech University, Lubbock, TX 79409

Total genomic DNA was isolated from study plants and was hybridized with 32P-labeled Allium fistulosum 'Ishikura' genomic DNA; Southern blots were performed. Plant materials were Allium cepa 'New Mexico Yellow Grano', the Allium fistulosum 'Heshiko' and 'Ishikura', and their $\mathrm{F}_{1}$ interspecific (Allium fistulosum $\mathrm{x}$ Allium сера) hybrids. Sequences with high identity to the labeled DNA hybridized strongly (i.e., A. fistulosum 'Ishikura' hybridized most strongly to itself, next with A. fistulosum 'Heshiko'). The least hybridization was observed when A. fistulosum 'Ishikura' was hybridized with A. cepa 'New Mexico Yellow Grano'. Intensity of the signals observed when DNA of the $F_{1}$ interspecific hybrids was probed with the 'Ishikura' DNA was as expected, with the signals intermediate between those of A. fistulosum to A. fistulosum and A. fistulosum to A. сера. A second study was performed to identify additional cytological markers in Allium. The 5srDNA and NOR genes from Triticum aestivum onto onion chromosomes using in situ hybridization. Evidence of hybridizations are the presence of fluorescing areas on the chromosomes.

GENETIC TRANSFORMATION AND REGENERATION OF TRANSGENIC SWEETPOTATO PLANTS.

Marceline Egnin* and C.S. Prakash, School of Agriculture, Tuskegee University, Tuskegee, AL 36088

This study aimed to optimize factors for the efficient delivery of foreign genes into sweetpotato using Agrobacterium tumefaciens and develop transgenic plants. Disarmed Agrobacterium C58 carrying a binary vector $\mathrm{pBI} 121 \mathrm{C}_{2} \mathrm{H}$ with $g u s A$, nptll, and the nutritional protein asp-l genes was used to cocultivate (4 days) petiole explants of the sweetpotato genotype P1318846-3. Pre-incubation of petioles for 3 days on MS medium with 2,4-D (0.2 mg.liter-1) before infection resulted in higher transformation. Putative transgenic shoots were obtained by transfer of petioles to MS medium with TDZ $(0.2$ mg.liter $\left.{ }^{-1}\right)$ and kanamycin ( 80 to $\left.140 \mathrm{mg} \cdot \mathrm{liter}^{-1}\right)$. The PCR amplification of gusA, nptll, and asp-1 genes in the 37 putative transgenic shoots showed that six plants contained the three genes. However, none of these plants showed histochemical expression of the gusA gene. The introduced gene may have been methylated resulting in the lack of its expression. DNA blot hybridization studies are underway to verify the presence and integration of the transgenes.

\section{Poster}

CHEMICAL MANIPULATION OF GRAPE DORMANCY UNDER SIMULATED TROPICAL CONDITIONS

Frank B. Matta* and Obadiah M. Njue, Department of Plant and Soil Sciences, Mississippi State University, Mississippi State, MS 39762

Defoliating chemicals (ammonium thiosulfate, ethrel, and thidiazuron) were evaluated on 8-month-old 'Canadice' and 'Concord' grapes. The effectiveness of chemical defoliators was determined 20 days after application. Vines were pruned after defoliation and dormancy breaking chemicals (thiourea, cyanamide, and gibberellic acid $\left(\mathrm{GA}_{3}\right)$ were applied 4 days later. All treatments were applied as sprays. All chemicals were effective in defoliating the vines of both cultivars. Generally, the higher concentrations (ammonium thiosulfate, ethrel, and thidiazuron at 15.15, 3.0, and $0.35 \mathrm{~g} \cdot \mathrm{liter}^{-1}$, respectively) were more effective. All chemicals reduced days to maximum budbreak of both cultivars. The higher concentrations (thiourea, cyanamide, and $\mathrm{GA}_{3}$ at $30.3,15.15$, and 0.75 g.liter ${ }^{-1}$, respectively) resulted in greater reductions in days to maximum budbreak. 'Con- 
cord' was later in reaching maximum budbreak. Total percent budbreak of both cultivars was increased by all chemicals at the higher concentrations. Cyanamide resulted in greater total percent budbreak in both cultivars.

\section{INFLUENCE OF PLANTING DATE ON 'CHANDLER' STRAW-} BERRY PRODUCTION

W.K.Patterson, Department of Horticulture, University of Arkansas, Fayetteville, AR 72701

'Chandler' strawberries were planted on four dates to ascertain optimum planting time under central Arkansas conditions. Greenhouse-rooted plugs were planted in four replications in a randomized complete-block design. Each replication was planted in double rows $6 \mathrm{~m}$ long on beds with 1.4-m centers. Plots were established on 9/28, $10 / 7,10 / 26$, and $11 / 5$. Number of branch crowns, yield, and number of runners/plant indicated that the earliest planting date was too late, and thus, the optimum date was missed. Equivalent yields of 16,173 $\mathrm{kg} \cdot \mathrm{ha}^{-1}$ were obtained from the earliest date, dropping to $8539 \mathrm{~kg} \cdot \mathrm{ha}^{-1}$ when planted 10 days later.

\section{COVER CROPS MAY DECREASE WEED GROWTH IN STRAW- BERRY FIELDS}

Julia Whitworth*, Department of Horticulture and Landscape Architecture, Oklahoma State University, Wes Watkins Agricultural Research and Extension Center, Lane, OK 74555

The usefulness of cover crops for weed management in strawberries were evaluated. Wheat (Triticum aestevumL.), rye (Secale cereale L.), and crimson clover (Trifolium incarnatum L.) were grown in individual pots then killed by tillage or herbicide and followed in the same pots by plantings of bermuda grass [Cynodon dactylon (L.) Pers.], yellow nutsedge (Cyperus esculentus L.), crabgrass [Digitaria ischaemum (Schreb.) Schreb. ex Muhl.], or strawberries (Fragaria $\times$ ananassa 'Cardinal'). Rye and wheat tilled into the medium generally increased the growth of strawberries and decreased the growth of bermuda grass. Rye and wheat residues appeared to suppress growth of weeds and strawberries when the residues remained on the medium surface. Crimson clover had little affect on the growth of weeds or strawberries. Yellow nutsedge and crabgrass were not significantly affected by cover crop residues.

EFFECTS OF POLLEN SOURCES ON OVULE AND BERRY DEVELOPMENT OF SOUTHERN HIGHBUSH BLUEBERRIES Yuehe Huang* and Gregory A. Lang, Department of Horticulture, Louisiana State University, Baton Rouge, LA 70803

To study the effects of pollen sources on ovule and berry development in southern highbush blueberries (Vaccinium corymbosum hybrids), 5-year-old 'Sharpblue' plants were moved into a greenhouse for self- and cross-pollination experiments. Cross-pollination with 'Gulfcoast' and 'O'Neal' as pollen sources increased fruit weight by $58.2 \%$ and $54.9 \%$, respectively, compared to self-pollination. Crosspollination did not affect the number of total and small ovules significantly but did double the number of fully developed ovules and increase the average ovule size by $14 \%$. The increase in number and size of fully developed ovules correlated with the significant difference in berry fresh weight between self- and cross-pollination. Crossand self-pollination showed good correlations between fruit fresh weight and number or cross-sectional area of fully developed ovules. There was a poor correlation between fruit fresh weight and the number or cross-sectional area of partially developed ovules. This study provides further evidence that berry size in southern highbush is influenced strongly by the development of fully developed ovules.

\section{EFFECT OF GIBBERELLIC ACID ON BLUEBERRIES GROWN UNDER NONSTRESS CONDITIONS}

James B. Magee, U.S. Department of Agriculture, Agricultural Research Service, Small Fruit Research Station, Poplarville, MS 39470

Rabbiteye blueberry (Vaccinium ashei) cultivars 'Climax', 'Premier', and Tifblue' were treated with gibberellic acid when $50 \%$ to $75 \%$ of the flowers of each were at stage 5 and again 10 days later. No known pollination stresses occurred during flowering, and the grow- ing conditions were near optimum. First harvest yields from the gibberellic-acid-treated plants of each cultivar were significantly lower than the yields from nontreated controls. Gibberellic acid treatment essentially delayed commercial quantity production by an estimated 5 to 7 days for each cultivar; for the early ripening cultivars 'Premier' and 'Climax', this delay could mean lower yields of more profitable early berries in the Mississippi-Louisiana growing areas. Harvest-season total yields from treated plants were lower than the yields from nontreated plants of each cultivar. Using gibberellic acid as a routine cultural practice may not be necessary for small-scale growers when pollination stresses, such as frost damage to flowers, do not occur.

\section{COLD HARDINESS OF RABBITEYE BLUEBERRY}

Frank B. Matta*, Gena R. Silva, and James M. Spiers, Department of Plant and Soil Sciences, Mississippi State, MS 397621; and U.S. Department of Agriculture-Agricultural Research Service, Small Fruit Research Station, Poplarville, MS 39470

Cold acclimation of 'Tifblue' rabbiteye blueberry was determined using differential thermal analysis (DTA). Electrolyte leakage and tissue browning test results were correlated with DTA. DTA showed that three exotherms occurred: exotherm 1 (ET) associated with extracellular freezing, exotherm 2 (CT) associated with tissue injury, and exotherm 3 (LTE) not associated with tissue injury. Maximum hardiness $\left(-20 \mathrm{C}\right.$ ) occurred in January. The $\mathrm{LT}_{50}$ measured by electrolyte leakage and tissue browning was about $-17 \mathrm{C}$ and $-15 \mathrm{C}$, respectively. Acclimation began in November and deacclimation in midFeb. 1994.

PRELIMINARY STUDY ON THE EFFECT OF ROOT ZONE TEMPERATURES ON VEGETATIVE GROWTH ANDLEAFMINERAL NUTRIENTS OF 'GULF COAST' BLUEBERRY PLANTS D.J. Makus*, U.S. Dept. of Agriculture, Agricultural Research Service, Weslaco, TX 78596; and J.M. Spiers, U.S. Department of Agriculture, Poplarville, MS 39470

The effect of root zone temperature (temp.) on 18-month-old plants of 'Gulf Coast' blueberries (predominantly Vaccinium corymbosum L.) grown in temperature-controlled water tanks during Summer 1993 were determined for plant growth and leaf nutrient status. Soil medium ( 1 sand : 1 peat, v/v) was maintained at or above $-20 \mathrm{k} \mathrm{Pa}$. Six singleplant replicates were placed in either a 24 or $31 \mathrm{C}$ tank. After 60 days, plants grown at $24 \mathrm{C}$ had more leaves, greater total leaf area, and higher leaf and stem fresh weight. Leaf moisture $(P<0.09)$ and stem dry wt $(P<0.07)$ were greater at the lower root temp. Root : shoot ratio and total root dry weight were not affected by root temp. Leaf $\mathrm{S}$ and $\mathrm{Cu}$ levels were higher and $\mathrm{NO}_{3}$ levels lower in plants grown at the $24 \mathrm{C} \mathrm{root}$ temp. compared to those grown in the $31 \mathrm{C}$ root temp. Nitrogen, $\mathrm{K}, \mathrm{Na}$, $\mathrm{Ca}, \mathrm{Mg}, \mathrm{P}, \mathrm{Fe}, \mathrm{Mn}$, and $\mathrm{Zn}$ (order of decreasing concentration) were not affected by root temp. The total $\mathrm{N}: \mathrm{NO}_{3}-\mathrm{N}$ ratio was higher at the lower root zone temp.

\section{EFFECT OF RATE OF BANDED PHOSPHORUS ON SWEET CORN YIELD}

Joseph M. Kemble*, Department of Horticulture, and Elizabeth A. Guertal, Department of Agronomy, Auburn University, AL 368495603

In 1994, a study was conducted in Crossville, Ala., to determine if differences in leaf $\mathrm{P}$ concentration and crop yield occurred when $\mathrm{P}$ was applied as either a broadcast or banded treatment. Phosphorus $(0,34$, 67,101 , and $\left.134 \mathrm{~kg} \cdot \mathrm{ha}^{-1}\right)$ was banded $(2 \times 2)$ or broadcast applied and incorporated before planting. Other nutrients were applied based on current recommendations and soil testing. As level of P increased from 0 to $134 \mathrm{~kg} \cdot \mathrm{ha}^{-1}$, fresh weight of harvested ears increased quadratically. There was no difference in fresh weight of harvested ears between banding and broadcasting. Yields were not maximized within the range of applied $\mathrm{P}$, although it seems that yield reaches a plateau near the highest rate of applied P. Percent of $\mathrm{P}$ in corn ear leaves did not differ among treatments. There was no difference in $\mathrm{P}$ leaf concentrations between the banded and broadcast treatments, indicating that response in yield occurred due to rate of $\mathrm{P}$ application, not method. 
EVALUATION OF GRAPE GERMPLASM FOR DOWNY MILDEW RESISTANCE

Maurus V. Brown*, James N. Moore, and Patrick Fenn, Department of Horticulture, University of Arkansas, Fayetteville, AR 72701

Trials were established in Fayetteville, Ark., in 1993 and in 1994 to evaluate grape germplasm for downy mildew resistance. Accessions were obtained from the national grape repositories in Geneva, N.Y.; Davis, Calif.; and the Univ. of Arkansas fruit substation, Clarksville. The 1993 trial contained 26 cultivars, eight selections, and 24 Vitis species; the 1994 trial contained 37 cultivars. Each trial had four single-plant replications. Plants were rated on a scale of 0 to 5 for sporulation, chlorosis, and necrosis on 23 Aug. and 26 Sept. 1994. Fungicides were not applied to the vineyard to better determine the level of natural downy mildew resistance. The results from both trials indicated that several grape accessions showed little or no symptoms of downy mildew, which suggests these have resistance that would be beneficial to use in a breeding program.

PAWPAW (ASIMINA TRILOBA) SEEDLING GROWTH AND DEVELOPMENT: INFLUENCE OF INCIDENT LIGHT INTENSITY AND FERTILIZATION REGIME

Lakesha Jones, Desmond R. Layne, and Michael G. Kwantes*, LandGrant Program, 129 Atwood Research Facility, Kentucky State University, Frankfort, KY 40601

The role of incident light intensity (light) and fertilization regime (Fert) on early growth and development of pawpaw seedlings in the greenhouse was investigated. Three-hundred and fifty stratified seeds were sown in 45 cubic inches. Rootrainer cells in Promix BX potting medium. A two-factor factorial design was used. Light was either ambient (Amb) or $80 \%$ shaded (Shade) Fert was 500 ppm of Peter's 20N-20P-20K plus soluble trace elements (+ Fert) or water (-Fert) applied twice weekly to runoff. Thirty uniform seedlings were selected at the two- to three-leaf stage for each of the four treatments. Treatment imposition was for 5 weeks until the 10- to 11-leaf stage (when seedlings would be transplanted). Plant height and leaf number was recorded three times weekly. After 5 weeks, 15 uniform plants per treatment were destructively harvested and leaf chlorophyll (chl) analysis was performed. Amb/+ Fert plants were $25 \%$ taller and had two more unfolded leaves, on average, than the other treatments. -Fert plants (Amb or Shade) had set terminal buds. The effect of Fert on chl was much greater under Amb than Shade conditions. For-Fert plants, total chl was reduced by $52 \%$ under Amb but only $30 \%$ under Shade compared to +Fert plants. Total biomass for Amb/-Fert seedling was double that in either Shade treatment and $40 \%$ greater than for Amb/ -Fert seedlings.

\section{PHENOLIC VARIATION IN LEAF POSITION IN APPLE}

M.E. Garcia*, R.C. Rom, J.B. Murphy, and G.W. Felton, Department of Horticulture, University of Arkansas, Fayetteville, AR 72701

The foliar phenolic content of 21 apple cultivars was evaluated. Ten leaves were sampled randomly from three positions on currentseason terminal shoots. Shoots were divided as tip, middle, and basal positions. The phenolic content was determined by spectrophotometric method $(390 \mathrm{~nm})$ using diphenylboric acid 2-aminoethyl ester as the reagent and caffeic acid as standard. Cultivars varied significantly in phenolic content. 'Stark Ultra Red' had the highest amount, and 'Liberty' had the lowest amount. Significant variations in the phenolic content due to leaf position were observed. Phenolic content was highest in leaves from the tip position, and it decreased toward the basal portion of the shoot. Factors affecting the phenolic content of apple cultivars will be investigated to determine apple $\times$ insect interactions.

THE OCCURRENCE OF PLUM LEAF SCALD ON PLUM CULTIVARS IN ALABAMA

B. Tangsukkasemsan, J.D. Norton, and G.E. Boyhan, Department of Horticulture, Auburn University, AL 36849

Naturally infected plum leaves were collected during Aug. and Sept. 1994 to evaluated for the presence of Xylella fastidiosa, the causal agent of plum leaf scald (PLS). Leaves were from trees at least
4 years old in variety trials at four locations in Alabama. ELISA tests for $X$. fastidiosa were used to determine the presence of the organism in infected trees. The symptoms also were evaluated with a rating index for PLS. Some plum cultivars (i.e., 'AU-Producer', 'Morris', 'Explorer', and 'AU-Cherry') showed high tolerance to PLS. Both ELISA tests and visual observation indicated that an Auburn Univ. seedling (CD-122) was free from this disease. PLS infection was lower in North Alabama compared to Central Alabama.

\section{PECAN COLD HARDINESS DETERMINED BY DIFFERENTIAL THERMAL ANALYSIS}

Frank B. Matta* and Amin Kawatin, Department of Plant and Soil Sciences, Mississippi State University, Mississippi State, MS 39762

Stem critical temperatures for September showed that 'Hughes' was later in acclimating than 'Jackson'. Maximum hardiness for all cultivars occurred in January and deacclimation in February. Bud critical temperatures for September and October also showed that 'Hughes' acclimated later than the other cultivars. Maximum hardiness for buds occurred in January and deacclimation in March. In December, the LT50 for the tetrazolium test, the electrolyte leakage test, and the tissue browning test were $-18,-20$, and $-20 \mathrm{C}$, respectively, as shown by differential thermal analysis of 'Desirable'.

APPLICATION OF UV-C AND BIO-CONTROL AGENT STRATEGIES TO CONTROL ROT OF FRUIT AND VEGETABLES

C. Stevens*, V.A. Khan, J.Y. Lu, George Washington Carver Agricultural Experiment Station, Tuskegee University, Tuskegee Institute, AL 36088; C.L. Wilson, U.S. Department of Agriculture, Agricultural Research Service, NAA Appalachian Fruit Research Station, Kearneyville, WV 25430; P.L. Pusey, U.S. Department of Agriculture, Agricultural Research Service, Southeastern Fruit and Tree Nut Research Laboratory, Byron, GA 31008; M.K. Kabwel, Y. Mafolo, and J. Liul, George Washington Carver Agricultural Experiment Station, Tuskegee University, Tuskegee Institute, AL 36088; E. Chalutz and S. Droby, Volcani Center, Bet Dagan, Israel

Applying low doses of ultraviolet light $(254 \mathrm{~nm}, \mathrm{~W}-\mathrm{C})$ reduces the incidence of brown rot of (Monilinia fructicola) peaches, green mold (Penicillium digitatum) of tangerines, and Rhizopus soft rot (Rhizopus stolonifer) of tomatoes and sweetpotatoes resulting from field infection and artificial inoculation. In most studies, applying postharvest fungicide (PF) was better than $\mathrm{W}-\mathrm{C}$ treatment. In this study, the effectiveness of combining a biocontrol agent, Debaryomyces hansenii (BC), with low UV-C dose for postharvest disease control was investigated. When these commodities were treated with $\mathrm{BC} 3$ days after W-C treatment, the reduction of storage rots was more effective than when UV-C was used alone. For example, the percent brown rot infection of artificially inoculated Elberta peaches 36 hours after inoculation of the nontreated control, peaches treated with UV-C, BC, $\mathrm{W}-\mathrm{C}+\mathrm{BC}$, and benlate were $100 \%, 55 \%, 67 \%, 12 \%$, and $12 \%$, respectively. The efficacy of $\mathrm{W}-\mathrm{C}+\mathrm{BC}$ was similar to when $\mathrm{PF}$ was used alone, indicating that an integration of UV-C treatment and $\mathrm{BC}$ can reduce storage rot to the levels of commercial PF treatment.

ASSESSMENT OF ATTITUDE AND KNOWLEDGE CHANGES OF SECONDARY HIGH SCHOOL STUDENTS PARTICIPATING IN A MULTIDISCIPLINARY, ACTIVITY-BASED, ENVIRONMENTAL SCIENCE CURRICULUM

Amy N. Campbell, J.M. Zajicek*, and C.D. Townsend, Departments of Horticultural Sciences and Agricultural Education, Texas A\&M University, College Station, TX 77843-2133

A study was developed to compare secondary high school students' knowledge and attitude changes toward environmental issues after the completion of an interdisciplinary instructional unit in environmental science. The population for the study was high school horticulture and environmental science students. The study consisted of four student groups, including two control groups and two experimental groups, one each from an environmental science class and a horticulture class. The control groups did not participate in the treatment, which consisted of an environmental mini-unit and plant propagation experiment that the experimental groups completed. Both 
student groups responded to a pre- and posttest questionnaire. There were no significant differences in overall attitude scores between treatment and control groups. Significant differences were noted in knowledge gains between the horticulture control group and treatment group, with students participating in the mini-unit scoring significantly higher in knowledge gain. There was also a positive correlation between attitude scores of students who had success with their propagation experiments. The results of this study indicate that it is important to test students' attitudes and knowledge when determining the effectiveness of new environmental curriculum. The high correlation between success in the propagation experiment included in the miniunit and attitude supports findings that an activity-based curriculum has the potential to raise the awareness of students on environmental issues.

\section{DENSELY PLANTED OKRA FOR DESTRUCTIVE HARVEST}

Yaying $\mathrm{Wu}^{*}$ and Brian A. Kahn, Department of Horticulture and Landscape Architecture, and John B. Solie, Department of Biosystems and Agricultural Engineering, Oklahoma State University, Stillwater, OK 74078

We are developing a mechanical harvest system for okra [Abelmoschus esculentus (L.) Moench]. Our objective was to identify a high-density (HD) plant arrangement and a harvest timing that would maximize marketable fruit yield per hectare with a destructive harvest. We compared destructively harvested plants grown at spacings of (in cm) $15 \times 15,23 \times 23$, and $30 \times 30$ with hand-harvested plants grown at $90 \times 23 \mathrm{~cm}$. Within HD treatments, marketable fruit weight increased inconsistently as plant density increased. The $30 \times 30-\mathrm{cm}$ spacing was not dense enough. Branching decreased and the position of the first marketable fruit attachment moved up as plant density increased. Delaying destructive harvest until many over-mature fruit were present often did not increase marketable fruit yield and always reduced the proportion of total harvested fruit weight due to marketable fruit. Overall, percentages of marketable yield obtained by destructive harvests of HD plants were low compared to the cumulative marketable yield from control plants. However, the labor-saving potential was high. A prototype machine for harvest of HD okra has been developed, and further testing is planned.

INFLUENCE OF PHOSPHORUS ON GAS EXCHANGE AND PLANT DEVELOPMENT AND NUTRIENT UPTAKE OF CHILE ANCHO AND BELL PEPPER PLANTS

Fred T. Davies, Jr.*, Sharon A. Duray, Lop Phavaphutanon, and Randy Stahl, Department of Horticultural Sciences, Texas A\&M University, College Station, TX 77843-2133 and Rocky Mountain Forest and Range Experiment Station, Fort Collins, CO 80526

The influence of $\mathrm{P}$ nutrition on gas exchange, plant development, and nutrient uptake of Capsicum annuum chile ancho 'San Luis' and bell pepper 'Jupiter' plants was studied. Plants were fertilized weekly using $250 \mathrm{ml}$ of a modified Long-Ashton solution, containing $0,11,22$, 44,66 or $88 \mu \mathrm{g} \mathrm{P} / \mathrm{ml}$. Phosphorus stress was evident with both pepper cultivars at 0 and $11 \mu \mathrm{g} \mathrm{P} / \mathrm{ml}$, with reduced plant growth and development: leaf number and area and fruit, leaf, stem, root, shoot, and total plant dry weight. The root : shoot ratio was greatest at $0 \mu \mathrm{g} \mathrm{P} / \mathrm{ml}$, reflecting greater dry matter partitioning to the root system. Greater $\mathrm{P}$ stress occurred at $0 \mu \mathrm{g} \cdot \mathrm{ml}^{-1}$ in 'San Luis' compared to 'Jupiter' $(88 \%$ vs. 58\% reduction in total plant dry weight compared to optimum $\mathrm{P}$ response). 'San Luis' was also more sensitive to P stress at $11 \mu \mathrm{g} \mathrm{P} / \mathrm{ml}$ than 'Jupiter', as indicated by the greater reduction in growth responses. With increasing $\mathrm{P}$ nutrition, leaf tissue $\mathrm{P}$ increased in both cultivars with maximum leaf tissue $\mathrm{P}$ at $88 \mu \mathrm{g} \mathrm{P} / \mathrm{ml}$. In 'San Luis', there were no differences in tissue $\mathrm{P}$ between plants treated with 0 and $11 \mu \mathrm{g}$ $\mathrm{P} / \mathrm{ml}$, whereas the 'Jupiter' plants treated with $0 \mu \mathrm{g} \mathrm{P} / \mathrm{ml}$ had the lowest tissue $\mathrm{P}$. Low $\mathrm{P}$ plants generally had the highest tissue $\mathrm{N}$ and lowest $\mathrm{S}$, $\mathrm{Fe}, \mathrm{Mn}, \mathrm{Zn}, \mathrm{B}, \mathrm{Mo}$, and Al. With both cultivars, gas exchange was lowest at $0 \mu \mathrm{g} \mathrm{P} / \mathrm{ml}$, as indicated by low transpiration (E), stomatal conductance $\left(\mathrm{g}_{\mathrm{s}}\right)$, and net photosynthesis $(\mathrm{A})$. Internal $\mathrm{CO}_{2}\left(\mathrm{C}_{\mathrm{j}}\right)$ and vapor pressure deficit were generally highest at $0 \mu \mathrm{g} \mathrm{P} / \mathrm{ml}$, indicating that $\mathrm{C}_{\mathrm{j}}$ was accumulating with lower $\mathrm{g}_{\mathrm{s}}, \mathrm{E}$, and $\mathrm{A}$ in these P-stressed plants. Generally, no $P$ treatments exceeded the gas exchange levels obtained by $44 \mu \mathrm{g} \mathrm{P} / \mathrm{ml}$ (full strength LANS) plants.
COMPARATIVECARBONBALANCEOFMYCORRHIZALAND NONMYCORRHIZAL PEPPER PLANT

Fred T. Davies, Jr.*, Randal S. Stahl, and Sharon A. Duray, Department of Horticultural Sciences, Texas A\&M University, College Station, TX 77843-2133 and Rocky Mountain Forest and Range Experiment Station, Fort Collins, CO 80526

Symbiotic mycorrhizal fungi increase the P uptake of agronomic, horticultural, and forestry crops. Little is known about the real-time dynamics of carbon balance (net gain of biomass resulting from photosynthesis less the respiratory costs) of plants colonized with mycorrhizae. Our objective was to determine the carbon balance of endomycorrhizal (VAM) chile pepper 'San Luis' (Capsicum annuum L.) as a model system for predicting plant response to limited P availability under elevated $\mathrm{CO}_{2}$. The increase in atmospheric $\mathrm{CO}_{2}$ is expected to result in increased plant productivity and greater demand for soil P, however, the lack of available soil P may become the most important nutritional problem limiting crop productivity. Under current conditions, the limitation of soil-P availability is an enormous problem that affects $25 \%$ of the world's arable lands. We are quantifying the carbon costs paid by the mycorrhizal plant under varying levels of $\mathrm{P}$ deficiency over the life cycle of the plant. Preliminary results from this study under ambient $\mathrm{CO}_{2}$ conditions indicate that there is a lower maintenance respiration and higher growth efficiency with mycorrhizal pepper plants under low soil-P conditions.

\section{TRANSPLANTING DEPTH OF PEPPER-BARE GROUND VS. MULCH EFFECTS}

William Terry Kelley* and Darbie M. Granberry, Extension Horticulture, University of Georgia, Rural Development Center, P.O. Box 1209, Tifton, GA 31793

Bell pepper (Capsicum annuum) has traditionally been transplanted to the top of the root ball or to the cotyledons of the transplant. Recent studies have shown increased and earlier yields are obtained by transplanting pepper deeper. Thus, a study was initiated to investigate effects of transplanting depth on pepper yield and plant growth. Pepper was transplanted to the top of the rootball, the cotyledons, and the first true leaf in two locations in 1994. 'Camelot' hybrid and 'Jupiter' (open pollinated) cultivars were planted into bare ground on Mar. 24 in Tifton, Ga. Only 'Camelot' was transplanted into a plastic mulch with drip irrigation on Mar. 28 in Cool Springs. Plots consisted of single rows of seven plants with data collected from the internal five plants. Treatments were replicated three times. Normal cultural and pest control practices were used at both locations. Plant measurement data were taken 5 weeks after transplanting. Yield data were collected at harvest. Total weight per plant of three harvests was significantly greater with peppers planted to cotyledons and first true leaf than those planted to the rootball in 'Jupiter'. There was no significant effect of planting depth on 'Camelot', although there was a distinct trend toward greater yield with deeper planting on plastic. The same trend was evident for average weight per plant and average number of fancygrade peppers per plant. Average stem diameter, plant height, and length of largest leaf were all greater among deeper planted peppers. Deeper planting seems to have a positive effect on yield and plant growth, particularly with hybrid pepper planted into a plastic mulch.

\section{ROW SPACING AFFECTS YIELD OF MACHINE-HARVESTED GREEN-MATURE SOUTHERNPEAS}

Blair Buckley* and Katharine Pee, Calhoun Research Station, Louisiana Agricultural Experiment Station, Louisiana State University, Agricultural Center, Calhoun, LA 71225

Yield of southernpeas machine-harvested at the green-mature stage generally have not been sufficient for machine-harvest to be profitable. Using narrow row spacings has been proposed to increase yield per hectare. A study was conducted in 1993 and 1994 to examine the effect of row spacing on yield of machine harvested green-mature southernpeas. 'Texas Pinkeye' was planted at row spacings of 53, 89, and $107 \mathrm{~cm}$ single drilled (SD), and $107 \mathrm{~cm}$ double drilled (DD). Marketable yield from the 53-cm row spacing was greater than from the wider row spacings. The yield response was primarily linear. Marketable yield from the DD $107-\mathrm{cm}$ row spacing did not differ 
significantly from that of the SD 107-cm row spacing. Marketable yield from the DD 107-cm row spacing was less than that from the 53$\mathrm{cm}$ spacing. The plant population per hectare for the two treatments was the same. In 1993, there was a linear response for percentage of pods mature at harvest. The percentage of mature pods was greatest for the $53-\mathrm{cm}$ row spacing.

EFFECTS OF LEONARDITE AND SEAWEED ON TOMATO, ZINNIA, AND MARIGOLD SEEDLINGS

A.J. Pertuit, Jr., Department of Horticulture, Clemson University, Clemson, SC 29634-0375

Leonardite additions $(0,1 / 16,1 / 8,1 / 4$, or $1 / 3$ volume leonardite/ volume medium) were more effective if applied only before (Expt. 1) than if applied before and after transplanting (Expt. 2). In Expt. 1, root dry weight (4 weeks after transplanting) of marigold increased $58 \%$ to $152 \%$ with $1 / 3$ leonardite (by volume) best; zinnia, $15 \%$ to $150 \%$, with no differences from $1 / 8$ to $1 / 3$ volume; tomato, a $64 \%$ increase at $1 / 8$, a $57 \%$ increase at $1 / 4$, and a $47 \%$ increase at $1 / 3$ volume, with no differences among $1 / 8$ to $1 / 3$ volume. In Expt. 2, 1/3 leonardite addition inhibited potential root growth. No differences in stem caliber or shoot length or dry weight were found in Expts. 1 or 2. Maxicrop soluble-extract powder seaweed drenches increased roots by $\approx 21 \%$, as did Maxicrop cold processed seaweed extract liquid (1:500). All extracts were applied 4 times beginning a week after transplanting. The most significant find was a $65 \%$ increase in root dry weight and a 7\% increase in stem caliber with Maxicrop cold processed seaweed extract drenches (1:200). No differences in shoot length or dry weight were found.

CONTROL OF BLACK SPOT ON ROSES WITH CYPROCONAZOLE USED AS A DRENCH

William E. Roberson, H. Brent Pemberton, and George L. Philley, Texas A\&M University, Agricultural Research and Extension Center, P.O. Box E, Overton, TX 75684

To determine the efficacy of cyproconazole for control of black spot [Marssonina rosae (Lib.) Lind] when applied as a drench, treatments of $0,32.5,65,97.5$ and $130 \mathrm{~g}$ a.i./ha were initiated 9 May 1994 on individual Rosa 'Peace' plants in a randomized completeblock design. Treatments were applied once per month until 18 Oct. 1994. Data were taken in July, Sept., and Nov. 1994 when separate disease and defoliation ratings were assigned. By July, the controls were heavily infected; the higher treatment rates resulted in significant control. By September, the disease and defoliation ratings exhibited a linear response with cyproconazole rate, with the highest treatment rate giving the best control. The relationship between disease and defoliation ratings and treatment rate remained the same in November, although there was increased disease incidence overall. No phytotoxicity was observed. These results indicate that soil applied treatments of cyproconazole can control black spot effectively on roses.

\section{CONSUMER PREFERENCE FOR ALTERNATE CHRISTMAS TREE SPECIES}

Ken Tilt, Bridget Behe, David Williams, Heath Potter*, and Dwight Bunn, Department of Horticulture, Auburn University, Auburn, AL 36849

A survey was developed evaluating the preference of consumers for purchasing three alternative Christmas tree species. Trees included: Pinus virginiana, a traditional Alabama Christmas tree; a containerized Ilex X 'Nellie R. Stevens'; and a cut X Cupressocyparis leylandii. Virginia pine and leyland cypress were rated higher than the holly. The average rating on a scale of 1 to 5 for the Virginia pine and the leyland cypress was 3.75 and 3.63 , respectively. Consumers rated the holly an average of 3.29. A rating of 1 indicated a strong negative response and a rating of 5 offered a strong positive response for buying the tree. The median rating for all three species was 4 , indicating that $50 \%$ of the participants rated them a 4 or higher. The mode, or most frequent rating, was 5 for all three species. Although the average rating for the holly was lower than the average for the Virginia pine and leyland cypress, the holly and the leyland cypress may have a market niche with $>50 \%$ of the respondents indicating that they would purchase the trees.
MEDIA AMENDED WITH BROILER LITTER COMPOST DID NOT AFFECT POINSETTIA GROWTH

V.V. Allen*, B.K. Behe, T.S. Krentz, and C.C. Montgomery, Department of Horticulture, 101 Funchess Hall, Auburn University, AL 36849-5408

Organic wastes have the potential to contaminate ground and surface water supplies when overused in agronomic crop production. Poultry manure contains organic $\mathrm{N}$ and can be composted and partially substitute for fertilizer or peatmoss in plant production. Our objective was to determine the effects on growth of poinsettias 'Freedom' and 'Supjibi Red' grown in media amended with broiler litter compost (BLC). Media were developed to resemble a commercial peat-lite medium by blending BLC, peatmoss, and perlite, by volume (BLC : peat : perlite) at 1:3:4, 2:2:4, 3:1:4, and 4:0:4. Plant height, growth indices, number of fully developed bracts, and visual marketability rating were not affected by adding BLC to the media.

\section{DETERMINING COST OF PRODUCTION FOR THREE ALTER- NATIVE NURSERY PRODUCTION METHODS}

C.C. Montgomery, B.K. Behe, J.L. Adrian, K.M. Tilt, Departments of Horticulture and Agricultural Economics and Rural Sociology, 101 Funchess Hall, Auburn University, AL 36949-5408

Aboveground container production revolutionized woody plant production. In-ground pot-in-pot container production combines the benefits of container production with traditional field production. Our objective was to determine the specific costs of production for fieldgrown, aboveground container, and pot-in-pot production methods for Lagerstroemia indica. We found differences in production cost with varying levels of input required by each production method. Pot-in-pot production systems had higher fixed and variable costs and a higher initial capital investment compared to the other two production methods. However, per unit production costs were similar to aboveground container production due to lower labor and equipment requirements.

\section{A FIELD STUDY ON THE HEAT TOLERANCE OF 'GERMAN RED' CARNATION}

Tim D. Davis*, Daksha Sankhla, and Narendra Sankhla, Texas A\&M University Research and Extension Center, 17360 Coit Road, Dallas, TX 75252-6599

Carnation cultivars 'German Red' and 'Chabaud' were planted in the field in Dallas, Texas, on 26 May 1994. During the subsequent 3 months, the average daily high temperature was $33 \mathrm{C}$, and the average daily low temperature was $22 \mathrm{C}$. 'German Red' plants increased in height and diameter several-fold during this period. In contrast, 'Chabaud' did not increase in height or diameter. 'German Red' plants began flowering in early August, and by 2 Sept., all of the plants were blooming. None of the 'Chabaud' plants produced flowers, and only $50 \%$ of the original plants were still alive on 2 Sept. Mean shoot dry weight per plant on 2 Sept. was $71.6 \mathrm{~g}$ for 'German Red' and only 2.4 $\mathrm{g}$ for 'Chabaud'. These results document the extraordinary heat tolerance of 'German Red' carnation. This plant not only survived the summer, but also grew and began blooming during the hottest time of the year.

CULTIVAR COMPARISON OF BUDDLEIA AS A CUT FLOWER T.S. Krentz*, B.K. Behe, V.V. Allen, and C.C. Montgomery, Department of Horticulture, 101 Funchess Hall, Auburn University, Alabama 36849

Buddleia sp., butterfly bush, is a large, arching shrub with spikeshaped inflorescences in a wide range of colors including pink, purple, yellow, and white. Our objective was to determine which cultivars of Buddleia had an acceptable postharvest life and potentially could be used as cut flowers. Stems of 'Black Knight', 'Charming Summer', 'Empire Blue', 'Lochinch', 'Nanho Blue', 'Nanho Purple', 'Pink Delight', 'Royal Red', 'White Profusion', and 'Sungold' were harvested when one-third to two-thirds of the florets had opened. Within 2 hours of harvest, flower stems were recut under water, placed in vases containing $10 \mathrm{~g}$ Floralife/liter, and placed in a simulated consumer environment. Daily fresh weight, open and total length of inflorescence, and inflorescence color were measured. 'Charming 
Summer', 'Pink Delight', 'Royal Red', 'Sungold', 'Lochinch', 'White Profusion', and 'Nanho Blue' performed best.

\section{CONSUMER PREFERENCESFOR GERANIUMFLOWER COLOR} AND LEAF VARIEGATION

J.J. Hudson*, R.G. Nelson, and B.K. Behe, Departments of Horticulture and Agricultural Economics and Rural Sociology, Auburn University, AL 36849

Some consumer preference studies show that red is the most popular flower color. Most data analyses were univariate. Conjoint analysis allows simultaneous determination of attribute preferences without all alternatives being shown. Our purpose was to determine consumer preferences for geranium flower color, leaf variegation, and price simultaneously using conjoint analysis. Two-hundred and four consumers shopping at two Montgomery, Ala., garden centers in Apr. 1993 rated 25 composite geranium photographs. A lavender geranium, 'Danielle', with green and white leaf variegation priced at \$1.39 was most preferred. Flower color was most important in the purchase decision, followed by price. Leaf variegation was a minor consideration in the purchase decision.

WATER AND NITROGEN RETENTION IN ANNUAL LANDSCAPE BEDS AMENDED WITH A HYDROPHILIC POLYMER Jennifer L. Boatright, J.M. Zajicek*, and W.A. Mackay, Department of Horticultural Sciences, Texas A\&M University, College Station, TX 77843-2133

A study was conducted to test the ability of hydrophilic polymers to retain moisture in annual bedding plant beds in addition to reducing $\mathrm{NO}_{3}$ and $\mathrm{NH}_{4}$ leaching. Petunia plants were transplanted into raised concrete benches containing a drainage pipe that allowed for excess leachate to be collected. Beds that were treated with 0 or $366 \mathrm{~g} \cdot \mathrm{m}^{-2}$ of hydrogel and 0 or $186 \mathrm{~g}$ of ai $\mathrm{N}$. Watering of beds followed a strict irrigation schedule and soil moisture was monitored daily. At termination, plant dry weight was measured and analyses of plant tissue and leachate were conducted for $\mathrm{NO}_{3}$ and $\mathrm{NH}_{4}$ concentrations. Results from this study demonstrated that, under suboptimal conditions of minimal irrigation and fertilization, polymer incorporation had a significant effect on water, $\mathrm{NH}_{4}$, and $\mathrm{NO}_{3}$ retention in soils. Water leaching was decreased by $17 \% ; \mathrm{NH}_{4}$ retention was increased by $83 \%$; and $\mathrm{NO}_{3}$ retention, where additional $\mathrm{N}$ was added, was increased by $64 \%$ due to polymer incorporation. In addition, a $47 \%$ reduction in $\mathrm{NO}_{3}$ concentration of water leachate was detected when polymer was incorporated under minimal fertilization. Growth or $\mathrm{N}$ levels of petunia were not significantly affected by polymer incorporation.

\section{LOW-TEMPERATURE STORAGE OF MICROPROPAGATED} PLANTLETS UNDER SELECTED LMHT SPECTRA

Chieri Kubota* and Nihal C. Rajapakse, Department of Horticulture, Clemson University, Clemson, SC 29634-0375; and Roy E. Young, Department of Agricultural and Biological Engineering, Clemson University, Clemson, SC 29634-0357

'Green Duke' broccoli plantlets, which were ready for transplanting after 2 weeks of photoautotrophic (sugar free) culture under the conditions of $1100 \mu \mathrm{mol} \cdot \mathrm{mol}^{-1} \mathrm{CO}_{2}$ (outside the vessel), $22+4 \mathrm{C}$ air temperature, and $140 \mu \mathrm{mol} \cdot \mathrm{m}^{-2} \cdot \mathrm{s}^{-1}$ photosynthetic photon flux (PPF), were stored for 6 weeks at $5 \mathrm{C}$ in darkness or in white, red, or blue light at $2 \mu \mathrm{mol} \cdot \mathrm{m}^{-2} \cdot \mathrm{s}^{-1} \mathrm{PPF}$ (light compensation point at $5 \mathrm{C}$ ). Photoperiod was set at 24 hour/day during storage. Spectral quality significantly affected plantlet quality: stem length was longer and chlorophyll concentration of leaves was lower in red or in blue light than in white light or in darkness after 6 weeks in storage. Regardless of the spectral quality, light in storage maintained plantlet dry weight at a level comparable to that before storage; dry weight was reduced significantly in dark-stored plantlets. Spectral quality did not significantly affect the photosynthetic and regrowth potential of plantlets. All plantlets stored in light, regardless of light spectra, grew preferably and had similar dry weight and stem length after 9 weeks of transplanting to the greenhouse under natural light.
PHOTOSYNTHETIC RATES AND YIELD COMPONENTS OF EIGHT VEGETABLE AMARANTHUS GENOTYPES

Wayne F. Whitehead* and Bharat P. Singh, Agricultural Research Station, Fort Valley State College, Fort Valley, GA 31030-3298

Over 2 years, eight vegetable amaranth (Amaranthus spp.) genotypes were grown in a yield trial. Data on yield and gas exchange rates were obtained. On 16 July 1993 and 27 June 1994, all genotypes (Hinchoy VL \& GL, RRC numbers 389, 701, 843, 1034, 1186, \& PI349553) were planted in a randomized complete-block design with four replications. Plants were harvested $\approx 44$ days after planting. Net photosynthesis $\left(\mathrm{P}_{\mathrm{n}}\right)$, transpiration $(\mathrm{E})$, green yield (GYLD), and leaf fresh weight $(\mathrm{LFW})$ are discussed. Significant variation $(P<0.01)$ existed across and within years for all treatments. Higher GYLD and LFW were found in 1994, and Pn and E were higher in 1993. Over both

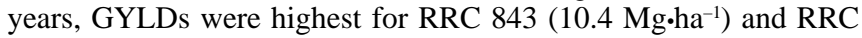
1034 (10.0 Mg.ha $\left.{ }^{-1}\right)$; RRC 1034 had the highest LFW (64.4 g/plant). The highest E rate $\left(8.9 \mathrm{mmol} \cdot \mathrm{m}^{-2} \cdot \mathrm{s}^{-1}\right.$ was in RRC 843 and RRC 1034. Genotype RRC 843 showed highest $\mathrm{P}_{\mathrm{n}}\left(27.5 \mu \mathrm{mol} \mathrm{CO}_{2} / \mathrm{m}^{2}\right.$ per second $)$. In general, RRC 843 and RRC 1034 outperformed other genotypes.

\section{SCREENING SWEETPOTATO GERMPLASM FOR SODIUM TOLERANCE IN HYDROPONIC CULTURE}

M.L. Pitts, P.P. David, and S. Riley, George Washington Carver, Agricultural Experiment Station, Tuskegee University, Tuskegee, AL 36088

Four sweetpotato breeding lines were tested for their sodium tolerance in sand culture. All plants were grown in the greenhouse in sterilized sand and watered daily with a modified half-Hoagland solution (N : K-1:2:4). Four sodium levels (0, 35, 70, and $105 \mathrm{ppm})$ were applied to the breeding lines in a split-plot design with four replications. Soil leachate was collected every 2 days and was measured for $\mathrm{P}, \mathrm{Na}$ concentration, and electrical conductivity. Plants were grown for 60 days. Preliminary results from analysis of soil leachate showed an increase in EC as sodium concentration increased 5 days after treatments were initiated. Potassium and $\mathrm{Na}$ concentration varied with each breeding line tested. Storage root fresh and dry weight were significantly affected by $\mathrm{Na}$ levels (i.e., lines tested were tolerant $\leq 70$ ppm Na).

\section{SUBJECTIVE AND OBJECTIVE EVALUATION OF COLOR IN BELL PEPPER}

E.H. Simonne*, J.T. Eason, J.A. Pitts, and J.T. Owen, Department of Horticulture, 101 Funchess Hall, Auburn University, AL 36849-5408

Bell pepper (Capsicum annuum L.) fruit are typically green in color at the immature stage, $1 / 3$ and $2 / 3$ colored during ripening, and red at maturity. However, this sequence does not apply to new varieties with immature colors of white or purple, intermediate colors of brown or black, and mature colors of yellow or orange. The study of physiological changes during ripening in such cultivars requires the description of color changes. Therefore, color changes of new bell pepper varieties were evaluated by subjective description and objective measurement of $\mathrm{L}, \mathrm{a}$, and $\mathrm{b}$. Color changes were described with a five-color stage scale. $\mathrm{L}, \mathrm{a}$, and $\mathrm{b}$ were affected significantly by variety $(P<0.01)$, and $\mathrm{a}$ and $\mathrm{b}$ were affected significantly by color stage $(P=0.95,0.01$, and 0.01 for $\mathrm{L}, \mathrm{a}$, and $\mathrm{b}$, respectively). Location and cultivar*location had no significant effect. For each cultivar, differences in a and $b$ values defined color stages that were clearly identifiable. When plotted, color measurements ( $a$ and $b$ ) were in good agreement with the verbal descriptions. Therefore, measurements of $\mathrm{L}, \mathrm{a}$, and $\mathrm{b}$ are not systematically necessary when referring to bell pepper colors.

\section{CORNUS FLORIDA POLLEN ONTOGENY}

K.R. Malueg*, S.E. Schlarbaum, E.T. Graham, and R.N. Trigiano, Institute of Agriculture, The University of Tennessee, Knoxville, TN 37901-1071

Development of Cornus florida L. pollen was monitored using standard paraffin histological techniques and light microscopy. Terminal buds (putative floral buds) were collected over a 6 weeks from mature landscape trees located on The Univ. of Tennessee Agricultural Campus, Knoxville. Examination of samples taken at 3- to 7-day 
intervals revealed variations in development representing 1- to 2-week differences between florets in a single inflorescence, florets on the same tree, and florets from different trees. Floral initiation occurred before 19 July in the 2 years of this study. Pollen development followed typical angiosperm stages: tapetal cells were multinucleate, pollen tetrads were tetrahedral, and meiosis occurred late in the developmental period. Pollen grains appeared morphologically mature by early September in both years.

\section{Sweetpotato Collaborators}

\section{RESPONSE OF SWEETPOTATO CULTIVARS TO} METOLACHLOR

Wayne C. Porter*, Louisiana State University Agricultural Center, Louisiana Agricultural Experiment Station, Hammond Research Station, Hammond, LA 70403

Metolachlor herbicide is being evaluated for preemergent weed control in sweetpotatoes due to its ability to control yellow nutsedge (Cyprus esculentus) and rice flatsedge $(C$. iria). Registration of metolachlor has been delayed because of reports in North Carolina of injury to sweetpotato roots. This study was initiated to determine the response of sweetpotato cultivars to metolachlor rates. Metolachlor at $1.12,2.24$, and $3.36 \mathrm{~kg} \cdot \mathrm{ha}^{-1}$ was applied to 'Beauregard', 'Hernandez', 'Jewel', and 'Darby' sweetpotatoes after transplanting. All rates of metolachlor provided good control of sedges. No significant cultivar $\times$ metolachlor interactions were found in the yield of no. 1, canners, marketable, or percent no. 1 sweetpotatoes. In plots treated with metolachlor at $2.24 \mathrm{~kg} \cdot \mathrm{ha}^{-1}$, only 'Beauregard' sweetpotatoes produced jumbo grade roots. No evidence of misshapen roots due to any herbicide rate was noted.

RESPONSEOF SWEETPOTATOES TO WINTER COVER CROPS Wayne C. Porter*, Louisiana State University Agricultural Center, Louisiana Agricultural Experiment Station, Hammond Research Station, Hammond, LA 70403

Rye, wheat, hairy vetch, ryegrass, and Austrian winterpea were evaluated for effects on weed control and sweetpotato production. Sweetpotatoes were transplanted into these cover crops after the cover crops had been killed with glyphosate and mowed. One-half of each plot was treated with clomazone herbicide and one-half was not treated. Plots with rye residues contained fewer goosegrass, rice flatsedge, ground cherry, and smooth pigweed plants than other cover crop plots. Sweetpotato plant vigor was greatest in the rye plots. Goosegrass, crabgrass, groundcherry, and eclipta were controlled in cover crop plots treated with clomazone. Sweetpotato plant vigor was better in the plots treated with clomazone than in plots with a cover crop only. Highest yields of no. 1 grade and total marketable sweetpotatoes were in rye and ryegrass cover crop plots, with or without clomazone. Sweetpotatoes grown in Austrian winterpea plots without clomazone produced the lowest yields. There was an increase in yield of sweetpotatoes in all cover crop plots treated with clomazone.

GENETIC RELATIONSHIPS AMONG U.S. SWEETPOTATO CULTIVARS ANALYZED BY DNA AMPLIFICATION FINGERPRINTING

C.S. Prakash*, G. He, and R. Jarret, Tuskegee University, School of Agriculture, Tuskegee, AL 36088 and U.S. Department of Agriculture, Agricultural Research Service, Griffin, Ga.

The PCR-based DNA amplification fingerprinting (DAF) approach was used to investigate the evolutionary relationships among 30 U.S. sweetpotato cultivars. Phenogram and pairwise similarity matrix based on Jaccard's coefficients showed relationships among U.S. cultivars and their progenitors to be consistent with the pedigree history. The genetic variability of U.S. cultivars was relatively low (compared to a sample of global collection). Many older U.S. cultivars formed a cluster in the principal coordinate analysis, suggesting their narrow genetic base, but new cultivars, such as 'Regal' and 'Excel', showed greater divergence. Somatic mutants showed close genetic similarity with their wild types and yet distinct in fingerprint profiles (e.g., 'Resisto' and 'Copper Resisto'; 'Redmar' and 'Goldmar'). All cultivars showed unique DAF profiles, and thus, the DAF approach enabled cultivar identification. 'Centennial' showed high similarity to major U.S. cultivars such as 'Jewel' and 'Rojo Blanco'. 'Regal' and its open-pollinated offspring 'Excel' showed high similarity with each other. 'Jewel', the most leading sweetpotato cultivar in the United States, clustered closely to its parent 'Nugget' (83\%). Carver, a selection from a cross 'Centennial' $x$ 'Jewel', showed 75\% similarity with 'Jewel' and 63\% similarity to 'Centennial'. 'Scarlet', a mutant of 'Jewel', appeared in the same cluster as 'Jewel' but showed only $68 \%$ similarity. Our results show that DAF may be an useful approach in elucidating evolutionary relationships among sweetpotato cultivars.

\section{DEVELOPMENT OF TRANSGENIC SWEETPOTATO AND} ANALYSIS OF TRANSGENE EXPRESSION

C.S. Prakash*, O. Zheng, and A. Porobodessai, School of Agriculture, Tuskegee University, Tuskegee, AL 36088

Stable, transgenic, sweetpotato plants have been developed using an improved somatic embryogenesis consisting of 1) stage I- explants incubated in darkness for 14 days on MS medium with 2,4D (2.5

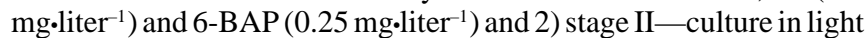
for 14 to 28 days on MS medium with ABA $\left(2.5 \mathrm{mg}^{-1 i t e r}{ }^{-1}\right)$. Petiole or leaf explants of the genotype PI318846-3 were co-cultivated with Agrobacterium tumefaciens EHA 101 containing gusA::nptII fusion gene. Transgenic somatic embryos were selected on a kanamycin medium $\left(100 \mathrm{mg} \cdot \mathrm{liter}^{-1}\right)$. The PCR analysis of the transgenic sweetpotato plants showed the presence of foreign genes in the sweetpotato genome. About 100 transgenic plants are being maintained under laboratory and greenhouse conditions. All the transgenic plants showed a strong expression of gusA gene in the histochemical GUS assay but showed quantitative differences in the chemiluminescent assay. The CaMV35S promoter shows a differential expression because there was some degree of tissue- and organ-specificity in the gus A expression. All transgenic plants appear normal with no phenotypic aberrations and are being tested for productivity traits.

FATTY ACID COMPOSITION OF PLASMALEMMA LIPIDS ASSOCIATED WITH GENETIC VARIABILITY IN COLD TOLERANCE OF SWEETPOTATO IPOMOEA BATATAS. (L). LAM Arambage Abesinghe* and James O. Garner, Department of Plant and Soil Sciences, Mississippi State University, MS 39762

Storage roots of 'Beauregard' and 'Centennial' were used to identify varietal differences in fatty acid composition in plasmalemma lipids during storage conditions. Total plasmalemma fatty acid composition of glycolipids and phospholipids in storage roots of 'Beauregard' and 'Centennial' did not differ. The fatty acid composition of MGDG and DGDG in storage root plasmalemma was $>50 \%$ unsaturated fatty acids in 'Beauregard'. The high percentage of 18:2 (65.44\%) fatty acid compared to 'Centennial' (19.70\%) and $79.35 \%$ total unsaturated fatty acid content in MGDG may contribute to low temperature tolerance in 'Beauregard'. The higher percentages of 16:1 and 22:1 fatty acids in 'Centennial' compared to 'Beauregard' contributed to MGDG fatty acid unsaturation. However, these fatty acids have not been related to chilling tolerance.

\section{EFFECT OF TOPSOIL THICKNESS ON SWEETPOTATO PRO-} DUCTION

R.C. Sloan, Jr.*, D.E. Pettry, P.G. Thompson, W.B. Burdine, Jr., J.L. Main, Plant and Soil Sciences Department, Mississippi State, MS 39762

'Beauregard' and 'Centennial' were planted in plots of four different topsoil thicknesses $(0,3,6$, and 9 inches) to evaluate the effect of topsoil thickness on sweetpotato production. In 1994, the 0-inch topsoil treatment produced a greater total marketable yield for 'Beauregard' than did the 6- and 9-inch topsoil for 'Centennial'. The 
0 - and 9-inch topsoil produced a greater total marketable yield than did the 3- and 6-inch treatment. When averaged over 2 years, 1993 and 1994, there were no differences in total marketable yield in either 'Beauregard' or 'Centennial' due to topsoil thickness. Averaged over both years, topsoil thickness had no effect on weight, diameter, or length of 'Beauregard' roots.

\section{SWEETPOTATO WEEVIL RESISTANCE IN U.S. PLANT IN- TRODUCTIONS}

Paul G. Thompson*, John C. Schneider, and Boyett Graves, Department of Plant and Soil Sciences, Mississippi State University, Mississippi State, MS 39762

One hundred plant introductions (PIs) were evaluated for sweetpotato-weevil resistance in experiment station field trials for 2 years in Beaumont, Miss. Weevil infestation was accomplished by applying adult weevils in year 1 and weevil infested roots in year 2 . The percentage of uninjured roots ranged from $38 \%$ in 'Centennial', the susceptible control, to $93 \%$ in PI538288. Severity of root and stem injury were measured in year 2 . Stem injury ratings on a scale of 0 , for no injury, to 4, for severe injury, ranged from 1.2 in PI564113 to 3.7 in 'Beauregard'. Root injury ratings on a scale of 0 to 5 ranged from 0.1 in PI538288 to 4.2 in 'Beauregard' (susceptible control). Thirtyfive PIs had lower root injury values than 'Regal' (resistant control), and the percentage of uninjured roots was higher in 45 PIs than in 'Regal'. These results suggest that genes are available in PIs for increased levels of weevil resistance in sweetpotato.

\section{GENETICS OF RAPD MARKERS IN SWEETPOTATO}

Liang L. Hong, Kittipat Ukoskit, and Paul G. Thompson*, Department of Plant and Soil Sciences, Mississippi State University, Mississippi State, MS 39762

Parents and progeny of four biparental crosses were analyzed for RAPD marker segregation. A range of 57 to 122 primers were tested in each cross, with an average of 82 . Average polymorphic primers and band numbers were 22 and 53, respectively. Of the 212 polymorphic bands, phenotypic segregation ratios were as follows: 133 fitted 1 dominant: 1 recessive, 58 fitted 3:1, 11 fitted ratios $4: 1$ to $19: 1$ and 10 were distorted. The 1:1 and 3:1 ratios were expected for either diploid or hexaploid segregation, and the 4:1 to 19:1 are exclusive to hexploid. A total of 14 pairs of markers were linked at map distances ranging from 2.1 to $36.5 \mathrm{cM}$. One common pair of linked markers was found in two separate crosses.

\section{EFFECT OF CANOPY TYPE ON WEED COMPETITION IN SWEETPOTATOES}

D.R. La Bonte*, Department of Horticulture, Louisiana State University Agricultural Center, Baton Rouge, LA 70803, H.F. Harrison U.S Vegetable Laboratory, Agricultural Research Service, U.S. Department of Agriculture, Charleston, SC 29414; and C.E. Motsenbocker, Department of Horticulture, Louisiana State University Agricultural Center, Baton Rouge, LA 70803

The objective of this study was to identify a sweetpotato canopy type ideally suited to suppress weed growth. With this knowledge, breeders could select sweetpotatoes that require less weed control. Diverse canopy types, ranging from upright, short-internode bunch types to long-internode trailing types, were compared in a split-plot design (hand-weeded and weed treatments). We also included lines with deeply lobed leaves (palmate) and more entire-leaf types. Our results show no significant differences between lines for total ground surface area covered after 6 weeks of growth, no differences in weed dry weight at harvest and few differences in canopy dry weight at harvest. Total ground surface area covered correlated positively with total yield, and weed dry weight correlated negatively to total yield. We were unable to identify individual lines that yield better when pressured with weeds compared to the hand-weeded control, but we were able to identify lines that yield poorly when pressured with weeds compared to the hand-weeded control. These results demonstrate the difficulty in categorically identifying a superior canopy.
RAPD MARKERS ASSOCIATED WITH SINGLE GENE TRAITS IN IPOMOEA TRIFIDA

Petra Wolters and Wanda W. Collins*, Department of Horticultural Science, North Carolina State University, Raleigh, NC 27695

Ipomoea trifida $(2 \mathrm{X}=30)$ is purported to be the wild Ipomoea species most closely related to the commercially grown Ipomoea batatas (sweetpotato, $6 X=90$ ). The two species can be crossed with much difficulty, but seed occur rarely. Ipomoea trifida has been shown to possess some agronomically desirable traits that are missing in sweetpotato (e.g., sweetpotato-weevil resistance). Attempts to locate morphological markers in the diploid trifida that would serve as indicators of successful crosses with sweetpotato resulted in the identification of two traits controlled by single genes: nectary color and male sterility. Both traits require flowering to identify, and flowering is often difficult to induce in Ipomoea species. An analysis of I. trifida accessions using RAPD molecular markers was undertaken. Using a segregant population resulting from crossing a green nectary, fertile plant with a yellow nectary, male, sterile plant, RAPD analysis resulted in clear markers for both the nectary color trait and the male sterility trait. These traits now can be identified in the absence of flowering plants.

INTER- AND INTRA-SPECIFIC VARIATION AMONG FOUR IPOMOEA SPECIES AS DETECTED BY RAPD ANALYSIS

Dapeng Zhang and Wanda Collins*, Department of Horticultural Science, North Carolina State University, Raleigh, NC 27695

To understand the prospects of applying the RAPD technique to assay genetic diversity in Ipomoea, four species (I. batatas, I. trifida, I. triloba, and I. Xleucantha) were analyzed for RAPD molecular markers. Six accessions of each species were used. Significant RAPD polymorphisms were detected within each species. Of 20 primers used, nine produced clear scorable polymorphic bands. The number of polymorphic bands produced per primer ranged from two to nine. Pairwide genetic distance was calculated based on "band sharing". The SAS-CLUSTER procedure was used to build a hierarchical species dendrogram. The four species were clearly separated by the clustering, which agrees with their existing taxonomic relationship. This study shows that RAPD analysis can be a powerful tool for identifying duplicates of germplasm acessions and for assessing genetic diversity. The procedures are relatively inexpensive and easy to perform and could be valuable in preliminary assessment of field genebank collections to separate species and indicate duplications in collected material.

EXTENT OF GENOTYPIC VARIATION AMONG SWEETPOTATOES PRODUCED THROUGH NODAL AND ADVENTITIOUS SPROUTS

Arthur O. Villordon* and Don R. La Bonte, Department of Horticulture, Louisiana State University Agricultural Center, Baton Rouge, LA 70803

Our research compared the extent of genomic variability between plants originating from adventitious sprouts and nodal cultures. Plant materials, derived from a single sprout and originating from a storage root each of 'Jewel,' 'Sumor,' and L87-95, were clonally propagated for seven generations nodally and through adventitious sprouts. PCRbased analysis using 15 random primers identified 58 scorable molecular markers, $37(63.79 \%)$ of which were shared by all three genotypes represented by 60 samples ( 10 nodal and 10 adventitiously derived plants/genotype). Of 29 putatively polymorphic markers, 24 $(82.75 \%)$ were putative polymorphisms across the entire data set. The remaining four $(13.79 \%)$ represented putatively fixed genotypic differences that were monomorphic within genotypes. A multidimensional scaling analysis differentiated seven $(23.33 \%)$ adventitiously derived phenotypic marker variants, compared to four $(13.33 \%)$ among nodal materials. Our results support previous findings that, relative to nonmeristematic tissues, meristematic regions strictly control cell division and DNA synthesis that exclude DNA duplication and other irregularities. 


\section{Vigna Crop Advisory Committee}

SELECTING VIGNA UNGUICULATA GERMPLASM FOR RESISTANCE TO COWPEA CURCULIO AND OTHER POD-DAMAGING INSECTS

Oyette L. Chambliss* and A. Gene Hunter, Department of Horticulture, Auburn University, AL 36849

Correlation analysis was used as an aid in developing a scoring system to determine superior lines among 288 entries evaluated for resistance to cowpea curculio, southern green stink bug, and leaffooted bug. The following selection criteria were used ( $\mathrm{min} / \mathrm{max}$ values): days to harvest (58 to 111); sound pods (17\% to $100 \%$ ); curculio larval weight ( 3.3 to $10.4 \mathrm{mg}$ ) and mortality ( $0 \%$ to $80 \%)$; larval exit holes per pod ( 0.0 to 2.2$)$ in a random sample of 25 pods; larval exit holes per pod (0.0 to 8.6) in a 10-pod sample selected for presence of punctures; punctures per pod (one to 15); punctures per exit hole (one to 14); exit holes per puncture (zero to one); curculio damaged seed (0\% to $93 \%$ ); stinkbug damaged seed ( $0 \%$ to $71 \%)$; sound seed (0\% to $98 \%$ ); pod length ( 8 to $25 \mathrm{~cm}$ ); pod weight (1.3 to $9.2 \mathrm{~g}$ ); seed per pod (five to 19 ); and average seed weight (10 to $327 \mathrm{mg}$ ). Lines ranking best for pod insect resistance were UCR212 = BAMBEY-5, UCR306 = IT82D713, UCR194 = BBR-42, PI- 218122, UCR90 = T W-3046, UCR200 = 24-1A, PI-115679, PI-145198, AU91P3 = CCR-20, UCR202 (BROWN SEED), and IT83S-911.

HIDDEN RESISTANCE TO CUCUMBER MOSAIC VIRUS IN HETEROGENEOUS POPULATIONS OF COWPEA (VIGNA UNGUICULATA) LINES AND CULTIVARS

R.O. Hampton, U.S. Department of Agriculture, Agriculture Research Service, Department of Botany and Plant Pathology, Oregon State University, Corvallis, OR 97331-2902

Cowpea cultivars Early Ramshorn and Dixie Queen, reported to be resistant to cucumber mosaic virus (CMV) by Sinclair and Walker in 1955, were reexamined for the existence of individual CMV-resistant genotypes within seedling populations. CMV-inoculated populations of these two cultivars became CMV-infected at rates of $60 \%$ and $80 \%$, respectively, as determined by DAS-ELISA. CMV-free plants were grown to maturity, seeds from these sources were planted, and secondgeneration seedlings were inoculated again with CMV. Rates at which these seedlings became CMV-infected were $10 \%$ and $24 \%$, respectively. The complementary $90 \%$ and $76 \%$ of these populations remained completely free of ELISA-detectable CMV and were saved to maturity. Evaluations of third-generation populations are being performed. Twenty additional cultivars and breeding lines also are being evaluated. Seedlings of 14 of the 22 cultivars/lines became $95 \%$ to $100 \%$ infected when inoculated with CMV. Results from eight of the 22 suggested that seedling populations contain CMV-susceptible and -resistant plants. Near isogeneic sublines of susceptible and resistant plants per cultivar/line are being conveyed to cowpea breeders for genetic analyses and breeding purposes.

\section{MATURITY SEQUENCE OF PINKEYE TYPE SOUTHERNPEA VARIETIES}

Oyette L. Chambliss* and A. Gene Hunter, Department of Horticulture, Auburn University, AL 36849

Twenty-two southernpea (Vigna unguiculata L. Walp.) cultigens were evaluated in field plots in southern, central, and northern Alabama to establish a set of varieties that would reach harvest stage sequentially. As first pods reached the dry stage, subjective ratings were made to estimate percentages of the following pod maturity stages: presnap, snap, mature green, and dry. Mature-green and dry stages were combined to give the total percentage of mature pods. From a general linear model analysis on SAS, lines were highly significant sources of variation in percentage of mature pods up to 83 days after planting. At least three maturity groups were apparent: $>80 \%, 50 \%$ to $80 \%$, and $<50 \%$ mature pods. These are represented by 'Santee Early Pinkeye', 'Coronet', 'Texas Pinkeye', and 'Pinkeye
Purplehull BVR'; 'C.T. Pinkeye Purplehull', 'Epoch', and 'Pinkeye Pinkpod'; and 'Mississippi Pinkeye' and 'Corona', respectively. All the plant introductions were in the late category and generally are not characteristic of commercial pinkeyes; they may be valuable in breeding for lateness in southernpeas.

\section{National Sweetpotato Collaborators}

\section{BEDDINGCOVER ALTERNATIVESFOR SWEETPOTATOPRO- DUCTION}

Jonathan R. Schultheis* and David W. Monks, North Carolina State University, Department of Horticultural Science, Raleigh, NC 276957609

Bedded sweetpotatoes are often covered with a rowcover to enhance sprouting. Our study was conducted to evaluate several rowcovers for earliness, plant yield, and plant quality (weight). In 1993 and 1994, variety ('Beauregard' and 'Jewel') and rowcovers (clear plastic; black plastic; photodegradable plastic; infrared transmissible plastic; Reemay polyester cover; and black plastic, which was then covered with a black plastic tunnel) were evaluated for their effects on plant production. Holes $\approx 1 \mathrm{~cm}$ in diameter were punched in the plastic $\approx 2$ weeks after planting to prevent exposing the seed roots to excessively high temperatures. Rowcovers were removed when plants began emerging from the soil, except for Reemay and the black plastic tunnels, which remained in place over the bedded plants until first plant harvest. Black plastic tunnels were placed back over the treatment bed each time plants were harvested. When $50 \%$ of the plants were $25 \mathrm{~cm}$ tall, all plants from the plot were cut 1 to $2 \mathrm{~cm}$ above the soil line. Plots were arranged in a randomized complete-block design and replicated five times. 'Jewel' produced plants earlier than 'Beauregard'. Covering beds with black plastic mulch and tunnels resulted in the first plant cutting being up to 42 days earlier than the other treatments, with no rowcover treatments producing plants the latest. The second earliest cutting was obtained when beds were covered with Reemay rowcover. Plant fresh weight was greater with the no cover treatments; black plastic tunnel treatments produced the lowest weight plants. Using black plastic tunnels consistently produced more plants than the other treatments. In the future, using rowcovers to enhance slower sprouting varieties should be examined.

\section{SUSTAINABLE NITROGEN ALTERNATIVES FOR} SWEETPOTATO PRODUCTION

William E. Little, North Carolina Cooperative Extension Service, Ag Center Drive, Nashville, NC 27856; Jonathan R. Schultheis, North Carolina State University, Department of Horticultural Science, Raleigh, NC 27695-7609; and Robert L. Mikkelsen, North Carolina State University, Soil Science Department, Raleigh, NC 27695-7619

North Carolina is a leading poultry producer in the United States. Thus, much waste by-product also is produced and must be handled in an environmentally responsible way. Using poultry and similar waste products as a fertilizer source for vegetables, such as sweetpotatoes, might serve as a viable use option. Our purpose was to determine the effectiveness of animal wastes and sludges as nutrient sources for sweetpotatoes. The effects of municipal solid waste, composted litter, fresh litter, and synthetic fertilizers were compared for their effects on yield and quality of 'Regal' and 'Beauregard' sweetpotato varieties. The test was planted as a split-plot randomized complete-block design with each treatment replicated four times. Planting was 3 June, and harvest was 27 Sept. 1994. Yields were similar when fertilized with either organic or synthetic nutrient sources. Root quality was excellent, regardless of fertilizer, because few culls resulted, and there were no differences between treatments. Sweetpotatoes can be successfully grown with various organic nutrient sources without affecting quality or yield and might be marketed as "organically grown" produce. This label may command a higher market price than sweetpotatoes grown traditionally with synthetic nutrient sources. 
INFLUENCE OF NITROGEN APPLICATION ON YIELD AND QUALITY OF 'BEAUREGARD' IN NORTH CAROLINA

Wilfred R. "Bill" Jester, III, North Carolina Cooperative Extension Service, Lenoir County Extension Center, Kinston, NC 28502-0747; Jonathan R. Schultheis, North Carolina State University, Department of Horticultural Science, Raleigh, NC 27695-7609; and Charles W. Averre, North Carolina State University, Plant Pathology Department, Raleigh, NC 27695-7616

Sweetpotato varieties differ in their ability to efficiently use N. This study was conducted to determine if time of $\mathrm{N}$ application affected root yield and quality in the variety Beauregard. Nitrogen sidedress singleapplication treatments were applied at 10,21, 28, and 35 days after transplanting. Two split application treatments were evaluated: 1) 44.8 $\mathrm{kg} \mathrm{N} / \mathrm{ha}$ were applied 10 days after transplanting and $22.4 \mathrm{~kg} \mathrm{~N} / \mathrm{ha}$ applied 21 days after transplanting and 2) $33.6 \mathrm{~kg} \mathrm{~N} / \mathrm{ha}$ were applied 21 and 35 days after transplanting. The $\mathrm{N}$ source was calcium nitrate (15.5-0-0) and totaled $67.3 \mathrm{~kg} \mathrm{~N} / \mathrm{ha}$ for all treatments. Plots were four rows and $6 \mathrm{~m}$ long, and treatments were randomized in five blocks. Harvested roots were sorted according to U.S. Dept. of Agriculture grading standards and weighed. Highest yields of U.S. no. 1 grade roots were obtained by applying N 21 to 35 days after transplanting. Total marketable yield was highest when application was made at 28 or 35 days after transplanting. Root length, at the $10 \%$ level of significance, was shorter when one vs. two $\mathrm{N}$ applications were applied. Using one $\mathrm{N}$ application compared with two $\mathrm{N}$ applications seems to be beneficial as shown by increased total marketable yields and yield of U.S. no. 1 roots and reduced root length.

\section{Pecan}

INFLUENCE OF SOIL AERATION ON PECAN TREE PERFORMANCE

Dan Chapman, G.R. McEachern, Laurence Sistrunk, John Lipe, Larry Stein, and J.B. Storey*, Department of Horticultural Science, Texas A\&M University, College Station, TX 77843-2133

Five Texas orchards were selected in Spring 1993 in commercial pecan counties for testing three types of soil aeration equipment. Mechanical aeration spikes were either 20 or $46 \mathrm{~cm}$ long, and a pneumatic spike was $20 \mathrm{~cm}$ long. The mechanical spikes are on a rolling cylinder that can be manufactured in sufficient lengths to fit the tree spacing in different orchards. The pneumatic probe is manually inserted into the soil so that a quick burst of 130-psi air can be delivered to effect soil profile fracturing. The fourth replicated treatment was an nontreated control. There were no differences in trunk diameter increases and yield in 1993 between May-applied replicated treatments. The May treatments and November measurements will continue for two more years to allow for differences in soil aeration to influence growth and yield. Shoot growth measurements will be taken in Spring 1995. Irrigation water has penetrated the soil under aerated trees more readily than in nonaerated controls.

\section{OIL REDUCTION OF SHELLED PECANS USING} SUPERCRITICAL CARBON DIOXIDE

Niels O. Maness* and Michael W. Smith, Department of Horticulture and Landscape Architecture; and C. Zhang and Gerald H. Brusewitz, Department of Biosystems and Agricultural Engineering, Oklahoma State University, Stillwater, OK 74078

Techniques to reduce the oil content of shelled pecans using supercritical $\mathrm{CO}_{2}$ have been developed, and the effect of partial oil extraction on kernel quality is being investigated. Extraction conditions induce little kernel damage and allow for up to $30 \%$ oil reduction. Extraction temperature, at 40 or $80 \mathrm{C}$, influenced kernel color. Regardless of temperature, extracted nut meat was lighter in color. Testa color increased in redness for kernels extracted at 80C compared to kernels extracted at 40C. Extracted oil was amber. Fatty acid composition of oil obtained with supercritical $\mathrm{CO}_{2}$ was essentially the same as oil obtained by organic solvent extraction and by cold press. Investigations to determine the effect of oil reduction on pecan shelf life are described. This research was supported by U.S. Department of Agriculture grant 92-34150-7190, Oklahoma Center for Advancement of Science and Technology grant AR4-044, and the Oklahoma Agricultural Experiment Station.

\section{Extension}

DELIVERING HORTICULTURAL INFORMATION VIA THE INTERNET ON A MOSAIC-BASED INFORMATION SERVER

R. Daniel Lineberger*, Paul Sittler, Ernie Frank, and Sam Cotner Texas Agricultural Extension Service, Texas A\&M University System, College Station, TX 77843

Aggie Horticulture (http://aggie-horticulture.tamu.edu) is the information server of the Texas horticulture program. Contents include information of interest to Texas A\&M students and faculty, faculty members at other universities, extension programs at the state and county level, members of the horticultural industries, and the consuming public. Aggie Horticulture is a registered server on the World Wide Web that can be accessed by any networked computer on the Internet that is running "browser" software such as Mosaic or Netscape. Modem access is gained using Internet connections provided through PPP or SLIP connections. Web browsers will change dramatically the way extension provides information to horticultural industries and the consuming public. Techniques for organizing a server and the challenges associated with maintaining a server for world access are discussed.

\section{OKLAHOMA GARDENING-TWENTY YEARS OF HELPING PEOPLE AND PLANTS GROW}

Steve Dobbs*, Department of Horticulture and Landscape Architecture, Oklahoma State University, Stillwater, OK 74078

Oklahoma Gardening, a television program produced by the Oklahoma Cooperative Extension Service, Departments of Horticulture and Landscape Architecture and Agricultural Communications, is tied for the longest running consecutively taped gardening program in the nation. The program airs weekly on Oklahoma's PBS affiliate and ranks as the top locally produced program in the viewing region, with a dedicated weekly audience of 150,000 gardening enthusiasts. As an Extension constituent, Oklahoma Gardening is successful at program identification, development, and evaluation-a new twist for most television programs. In addition to television programming, educational opportunities are available through tours of the 5-acre studio gardens located in the Oklahoma Botanical Gardens and Arboretum on the Oklahoma State Univ. campus where most of the shows are taped. Visitors touring the gardens increased 204\% from the previous year. Extension fundamentals of 1) program development and coordination, 2) volunteer training and activities, and 3) community and business involvement and support can be implemented effectively into television programming as shown by Oklahoma Gardening's productive 20-year history!

\section{COMMUNICATING COMPOSTING TO THE PUBLIC.}

Sandra A. Balch* and Dick L. Auld, Department of Plant and Soil Science, Texas Tech University, Lubbock, TX 79401-2122

As the public becomes more aware of environmental concerns, there has been a renewed interest in composting. Municipalities are promoting composting as a way to save diminishing landfill space. Although there are many successful composting programs, many would-be composters are thwarted by a lack of expertise, information, and follow-up support. Brochures, videos, and slide presentations present visual information, but hands-on instruction and active involvement in on-going programs has increased the likelihood of success. Integrating composting into established programs, such as community gardens, institutional programs, education curriculum, and demonstration sites, has proven an effective method of conveying composting information to the public. 